\title{
Windsor Group (Late Mississippian) stratigraphy, Magdalen Islands, Quebec: a rare eastern Canadian record of late Visean basaltic volcanism
}

\author{
Peter S. Giles \\ Natural Resources Canada, Geological Survey of Canada (Atlantic), P.O. Box 1006, Dartmouth, \\ Nova Scotia B2Y 4A2, Canada <pgiles@nrcan.gc.ca>
}

Date received 17 April 2008 Date accepted 02 December 2008

\begin{abstract}
The Magdalen Islands archipelago is the single site in the north-central Gulf of St. Lawrence where surface exposures of the Windsor Group, an important Mississippian (Visean) marine marker interval within the thick Late DevonianEarly Permian fill of the Maritimes Basin, permit stratigraphic comparison with the type Windsor Group and the correlative Codroy Group of western Newfoundland. The presence of volcanic rocks associated with regionally more typical marine carbonate rocks, evaporites, and fine-grained redbeds make this local Windsor Group succession unique in eastern Canada. The volcanic rocks, including vesicular and amygdaloidal basalts with minor pyroclastic rocks, are interstratified in surface exposures with middle Windsor Group gypsum, limestone, and siltstone of late Asbian age. Similar sedimentary suites higher in the Windsor Group, assigned biostratigraphically to the Brigantian and questionably the earliest Pendleian substages, lack any associated volcanic rocks (Île Boudreau) or are in tectonic contact with volcanic-bearing middle Windsor Group successions (Île d'Entreé). The Cap au Diable Formation, erected as a volcanic-dominated rock unit of the upper Windsor Group on the Magdalen Islands, is here abandoned. Thick salt deposits lacking intercalated carbonate rocks, which underlie and are presumed to have diapirically intruded middle and upper Windsor Group strata, are believed to represent the product of the first major cycle of Mississippian marine sedimentation in the region. The Magdalen Islands Windsor Group succession, except for its regionally unique volcanic component, is most comparable to that of south-central and eastern Nova Scotia in its overall character. This tectonically dismembered remnant of an apparently complete succession contrasts with rocks of similar age in southeastern New Brunswick and northwestern Nova Scotia which lack upper Windsor Group marine carbonate members and contain only a limited number of middle Windsor Group marine carbonate bands.
\end{abstract}

\section{RÉSUMÉ}

L'archipel des îles de la Madeleine constitue le seul emplacement dans le Centre-Nord du golfe du Saint-Laurent où des affleurements en surface du groupe de Windsor, intervalle de référence marin déterminant du Mississippien (Viséen) à l'intérieur de l'épaisse couche de remplissage du Dévonien tardif-Permien précoce du bassin des Maritimes, permettent une comparaison stratigraphique avec le groupe type de Windsor et le groupe corrélatif de Codroy de l'Ouest de Terre-Neuve. La présence de roches volcaniques associées à des couches rouges à grains fins, des évaporites et des roches carbonatées marines plus typiques à l'échelle régionale rendent cette succession locale du groupe de Windsor unique dans l'Est du Canada. Les roches volcaniques, notamment des basaltes vésiculaires et amygdaloïdes accompagnés d'une quantité modeste de roches pyroclastiques, sont interstratifiées avec de la siltite, du calcaire et du gypse de la partie médiane du groupe de Windsor dans des affleurements en surface remontant à l'Asbien tardif. Des séquences sédimentaires similaires de niveaux supérieurs du groupe de Windsor, rattachées biostratigraphiquement au Brigantien et de façon discutable aux sous-étages les plus précoces du Pendleien, sont dépourvues de roches volcaniques connexes (île Boudreau) ou se trouvent en contact tectonique avec des successions de roches volcaniques de la section médiane du groupe de Windsor (île d'Entrée). On abandonne dans les présentes la Formation de Cap au Diable, créée à titre d'unité lithologique à prédominance de roches volcaniques de la tranche supérieure du groupe de Windsor dans les îles de la Madeleine. Les dépôts épais de sel dépourvus de roches carbonatées intercalées, sous-jacents, qu'on suppose avoir pénétré diapiriquement les strates médianes et supérieures du groupe de Windsor, représenteraient le produit du premier cycle important de sédimentation marine mississippienne dans la région. La succession du groupe de Windsor et des îles de la Madeleine $\mathrm{a}$, mis à part sa composante volcanique unique à l'échelle régionale, un caractère général très comparable à celle du Centre-Sud et de l'Est de la Nouvelle-Écosse. Ce vestige tectonique- 
ment démembré d'une succession apparemment complète contraste avec les roches d'âge semblable dans le Sud-Est du Nouveau-Brunswick et le Nord-Ouest de la Nouvelle-Écosse d'où sont absents les membres carbonatés marins de la partie supérieure du groupe de Windsor et qui renferment seulement un nombre limité de bandes carbonatées marines de la partie médiane du groupe de Windsor.

[Traduit par la redaction]

\section{INTRODUCTION AND REGIONAL SETTING}

The Magdalen Islands lie near the centre of the Gulf of St. Lawrence in the western part of the Maritimes Basin (Fig. 1). The western Maritimes Basin covers an area of more than 200 000 square kilometres and has a sedimentary fill ranging from mid-Devonian to Early Permian in age. Total thickness of the basin fill exceeds $12 \mathrm{~km}$ in the deepest central portions of the basin, as determined from seismic reflection data(Durling and Marillier 1993).

The Windsor Group comprises a regional marker sequence within the Carboniferous succession. Where typically developed, the group is characterized by relatively thin marine carbonate rock units which were synchronously deposited over large areas, intercalated with evaporite units and nonmarine detrital clastic rocks (Giles 1981). With a long history

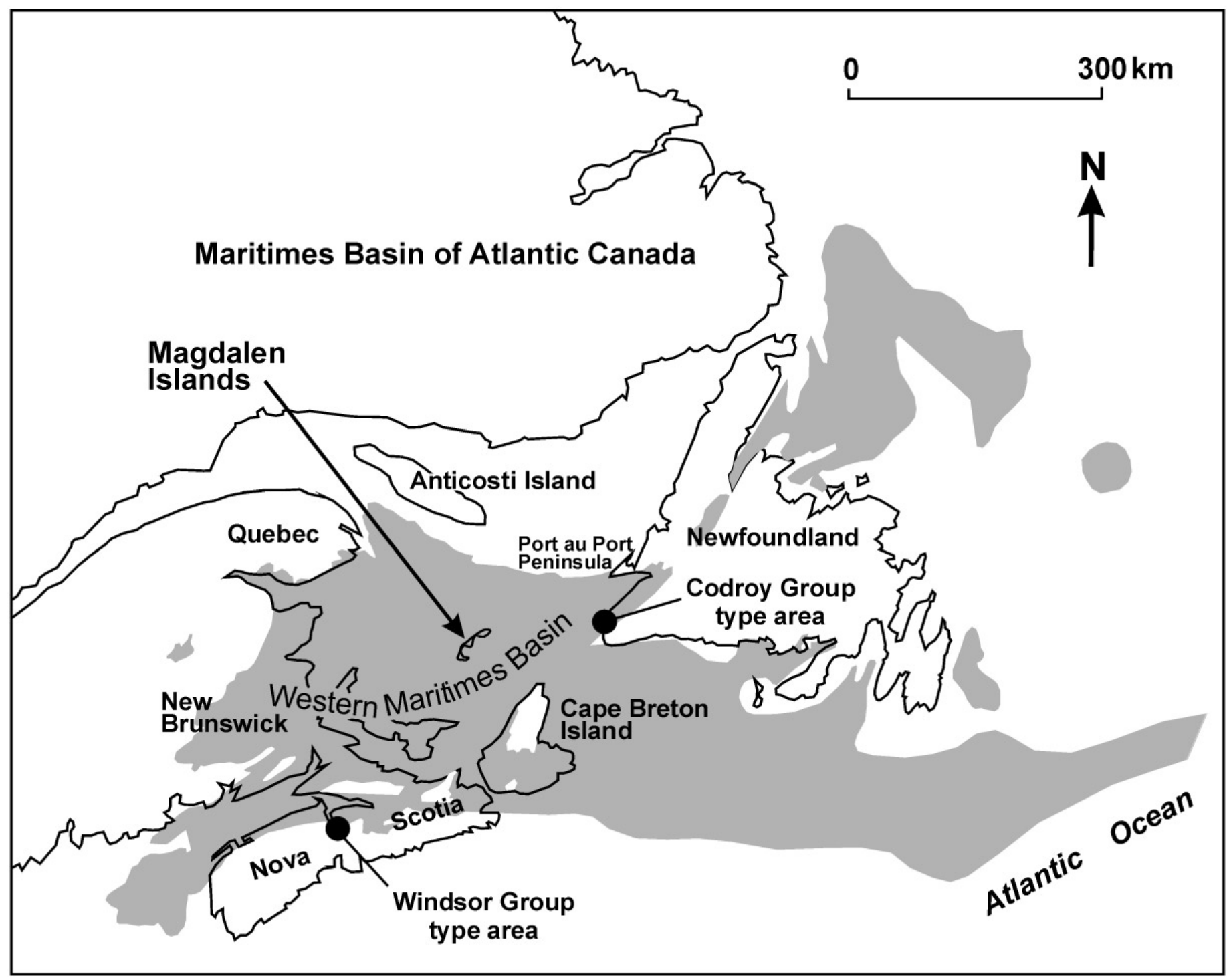

Fig. 1. Map showing the regional distribution of late Devonian to Permian rocks of the Maritimes Basin in Atlantic Canada. Type areas for the Windsor Group in southern Nova Scotia (Bell 1929) and the correlative Codroy Group in southwestern Newfoundland (Bell 1948) are indicated. 
of biostratigraphic research and a distinctive pattern of cyclic marine and non-marine sedimentation, the Windsor Group provides an excellent vehicle for basin reconstruction. Bedrock exposures on the Magdalen Islands provide a unique onshore opportunity to assess the stratigraphic succession in this part of the Maritimes Basin. Of particular interest in the Magdalen Islands succession are volcanic rocks, principally of basaltic composition, which are interbedded with Mississippian marine strata and which are known to occur in the Windsor Group only at this location.

The purpose of the present investigation is 1) to document the lithostratigraphy of the Windsor Group on the Magdalen Islands, 2) to assess biostratigraphic constraints on the position of the basaltic rocks within the Windsor Group, applying available micropaleontological and palynological data in order to better estimate the timing of basaltic extrusion, and 3) to place the succession within the regional stratigraphic framework of the Windsor Group.

\section{GEOLOGICAL SETTING}

The Magdalen Islands archipelago consists of a group of islands situated in the central portion of the Gulf of St Lawrence (Fig. 1). Carboniferous to Permian(?) bedrock underlies the islands, six of which are interconnected by modern sand spits and tombolos (Fig. 2). Windsor Group strata crop out on six of the islands, typically in fault-bound blocks, flanked by gentlydipping Permian(?) sandstone. The general structural configuration for the Windsor Group outcrop areas is best seen on the three largest islands, Havre aux Maisons, Havre Aubert, and Cap aux Meules (Fig. 3). There, major faults trending approximately east-west bound anticlinal horsts composed of volcanic and associated sedimentary rocks. These fault-bound structures are flanked by gently dipping strata of presumed Permian age, which unconformably overlie the Windsor Group at the single observed locality where the boundary is not a fault.

Windsor Group coastal exposures within the archipelago are typically spectacular and reasonably accessible, but are also severely deformed. Salt diapirism has been suggested as the mechanism responsible for bringing Windsor Group strata to the present surface and may be largely responsible for the complex, intensely sheared and folded character of the Mississippian succession (Brisebois 1979, 1981).

\section{PREVIOUS WORK AND THE DEVELOPMENT OF STRATIGRAPHIC NOMENCLATURE}

The strategic location of the Magdalen Islands from the perspective of regional Carboniferous studies has been appreciated since the early work of Clarke (1911) and Alcock (1941). Bell (1948, unpublished informal Geological Survey of Canada report, 15 pages) was the first to attempt to establish detailed stratigraphic relationships, relying heavily on his experience with the Windsor Group elsewhere in Atlantic Canada. He recognized, mainly using macrofaunal biostratigraphic evidence, that marine fossils of both the lower and upper biostratigraphic zones of the Windsor Group (Bell 1929) were represented in limestone beds exposed on the islands, assigning the terms 'Adele' and 'Coffin Island' beds, respectively, to the corresponding local lithostratigraphic subdivisions. Bell believed that the volcanic rocks are associated entirely with the lower 'Adele beds'. Bell assigned thick sandstones unconformably overlying the Windsor Group to the Alright Formation, a term no longer in use, and correlated the latter formation with rocks of the Canso Group elsewhere in Atlantic Canada. The term Canso also is no longer in use and has been replaced by the Mabou Group (see Ryan et al. 1991).

Sanschagrin (1964) produced the first modern geological map of the Magdalen Islands, building on the previous stratigraphic work of Bell and suggesting new terminology for the entire succession (Fig. 4). Sanschagrin assigned Windsor Group volcanic and associated sedimentary rocks to a single formation termed the Havre aux Maisons Formation. He named a lower Cap Adèle Member to which he assigned the beds of Bell's 'Adele Beds', and an upper Bassin aux Huîtres Member (Fig. 4) which corresponded to Bell's 'Coffin Island Beds'. Like Bell, Sanschagrin interpreted the volcanic rocks to lie entirely within the Adèle Member in the lower part of his Havre aux Maisons Formation. Sanschagrin (1964) reported volcanic rocks of his Havre aux Maisons Formation at a single additional locality on Île du Corps Morts, a small island approximately $16 \mathrm{~km}$ west of Île du Havre Aubert (Fig. 3, inset map 1). These exposures were not included in the present study as the island can be safely accessed only during exceptionally calm conditions. Above the Havre aux Maisons Formation, Sanschagrin named the Cap aux Meules Formation, replacing Bell's informal Alright 'formation'. He was the first to postulate that the sandstone above the Havre aux Maisons Formation might be as young as Permian in age, while still suggesting regional assignment to the Canso (presently Mabou) Group.

Brisebois $(1979,1981)$ prepared geological maps of the archipelago, significantly modifying the stratigraphic framework of Sanschagrin (1964). He retained the name Havre aux Maisons Formation but restricted the formation to the lower portion of Sanschagrin's earlier defined formation (Fig. 4). Brisebois $(1979,1981)$ described both volcaniclastic rocks and basaltic flows in his redefined Havre aux Maisons Formation, associated with gypsum, mudstone, and thin marine carbonate rocks. Members of the Havre aux Maison Formation established by Sanschagrin (1964) were abandoned. For the upper part of Sanschagrin's Havre aux Maisons Formation, Brisebois $(1979,1981)$ erected the Cap au Diable Formation, characterized by volcanic rocks represented principally by basaltic flows. He considered the Cap au Diable Formation to be laterally equivalent to Sanschagrin's Bassin aux Huîtres Member (Bell's Coffin Island Beds, Fig. 4), and to represent the upper part of the Windsor Group on the southern islands of the archipelago. The contact between Brisebois' Havre aux 


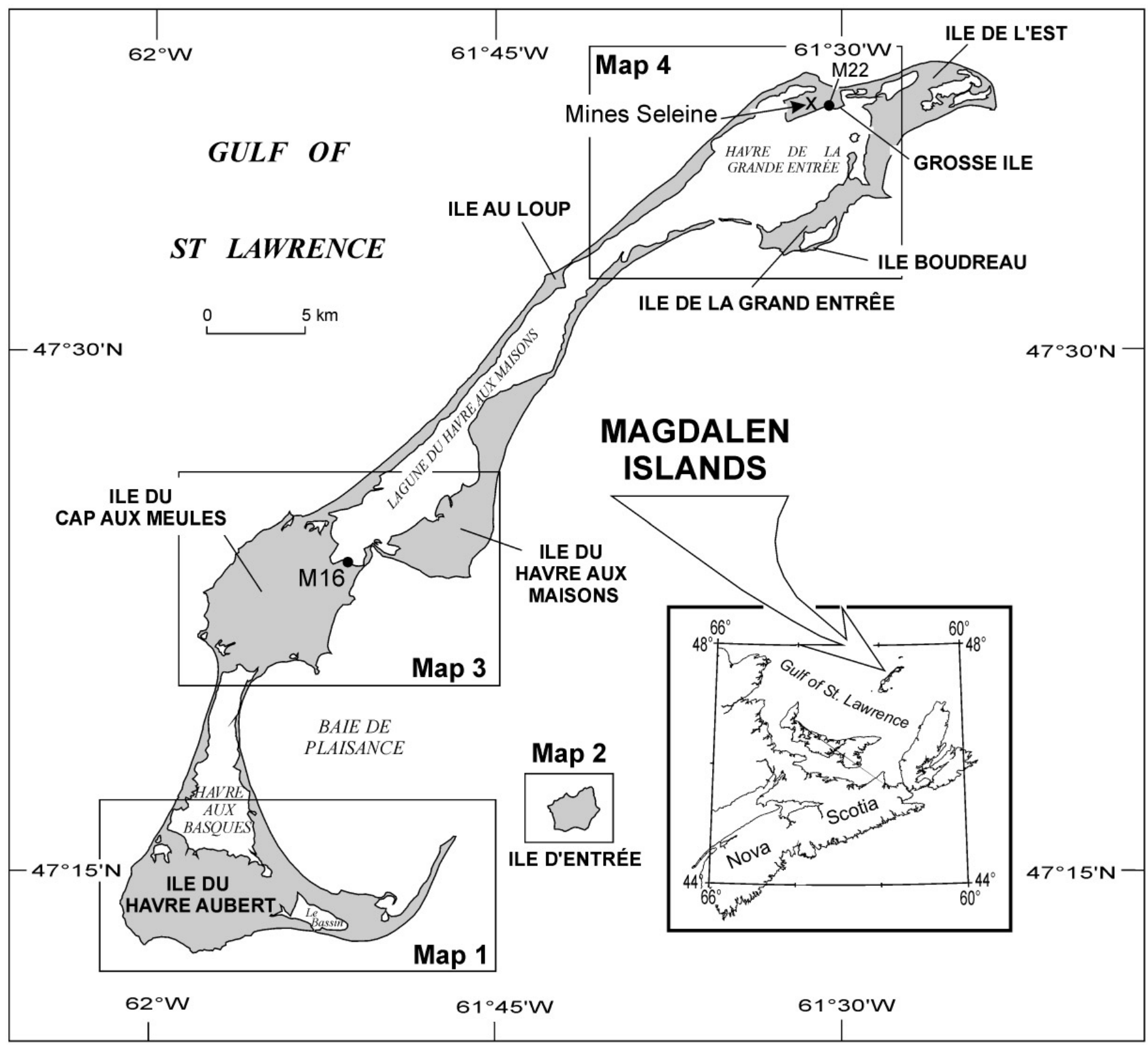

Fig. 2. The Magdalen Islands, with names as used by Brisebois (1981). The inset map shows the strategic location of the islands in the central portion of the Gulf of St. Lawrence. Numbered map portions 1, 2, and 3 are amplified in Fig. 3. Map 4 is enlarged in Fig. 9.

Maisons and Cap au Diable formations was reported to be transitional, and placed immediately above the highest interval of mudstone in the Havre aux Maisons Formation. Although Bell (1948) speculated on possible domal salt structures beneath the Magdalen Islands, Brisebois (1979, 1981) first documented thick salt deposits revealed by deep drilling. These beds were not formally named by Brisebois, who assigned them to the lower Windsor Group, lying beneath his Havre aux Maisons Formation. Several investigations of Windsor Group rocks exposed on the Magdalen Islands have relied heavily on the stratigraphy erected by Brisebois (1981) (see, for example, Barr et al. 1985; Plint and von Bitter 1986; Howie 1988).

Above the Windsor Group, Brisebois (1981) subdivided the Cap aux Meules Formation of Sanschagrin (1964) into a lower Étang du Nord Member, and an upper Étang des Caps Member (Fig. 4). The Étang du Nord Member comprises sandstone, siltstone, and mudstone with small amounts of dolomitic limestone. Brisebois (1981, p.30) reported an approximate thickness of $300 \mathrm{~m}$ for the member on Île du Havre Aubert. The overlying Étang des Caps Member comprises fine-grained 


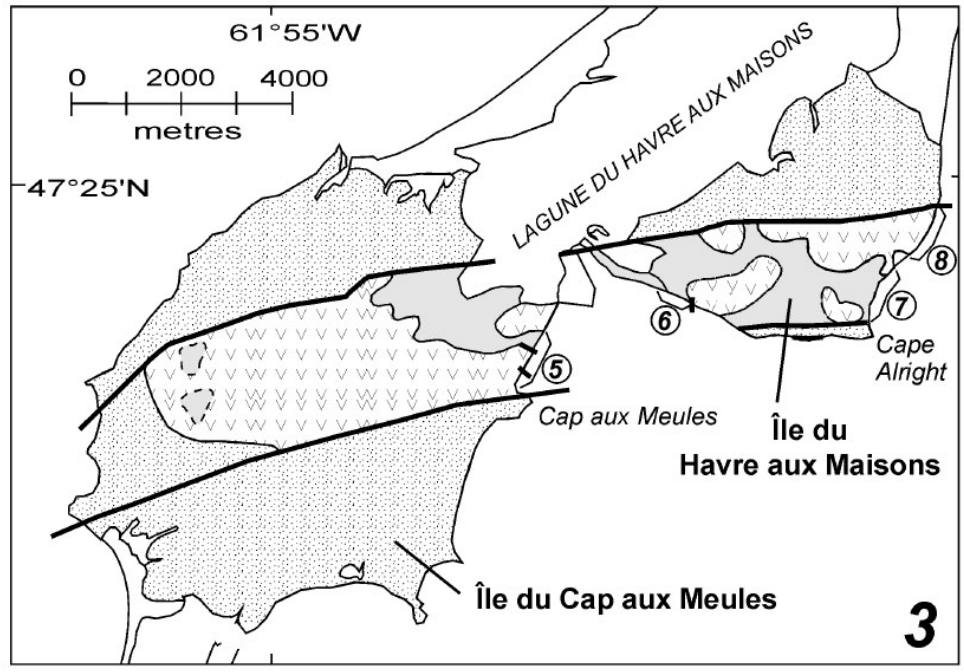

\section{CAP AUX MEULES FORMATION}

sandstone, red-brown, large-scale cross-stratification

HAVRE AUX MAISONS FORMATION Bassin aux Huîtres Member

ㅇํㄴ siltstone, limestone, gypsum (île d'Entrée only)

Cap Adèle Member

basalt, with minor associated sedimentary rocks siltstone, limestone and dolostone, gypsum, with associated basalt and pyroclastic rocks

\section{SYMBOLS}

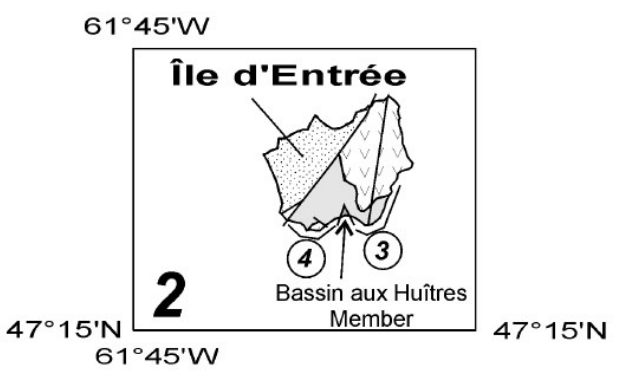

\section{Geological contact}
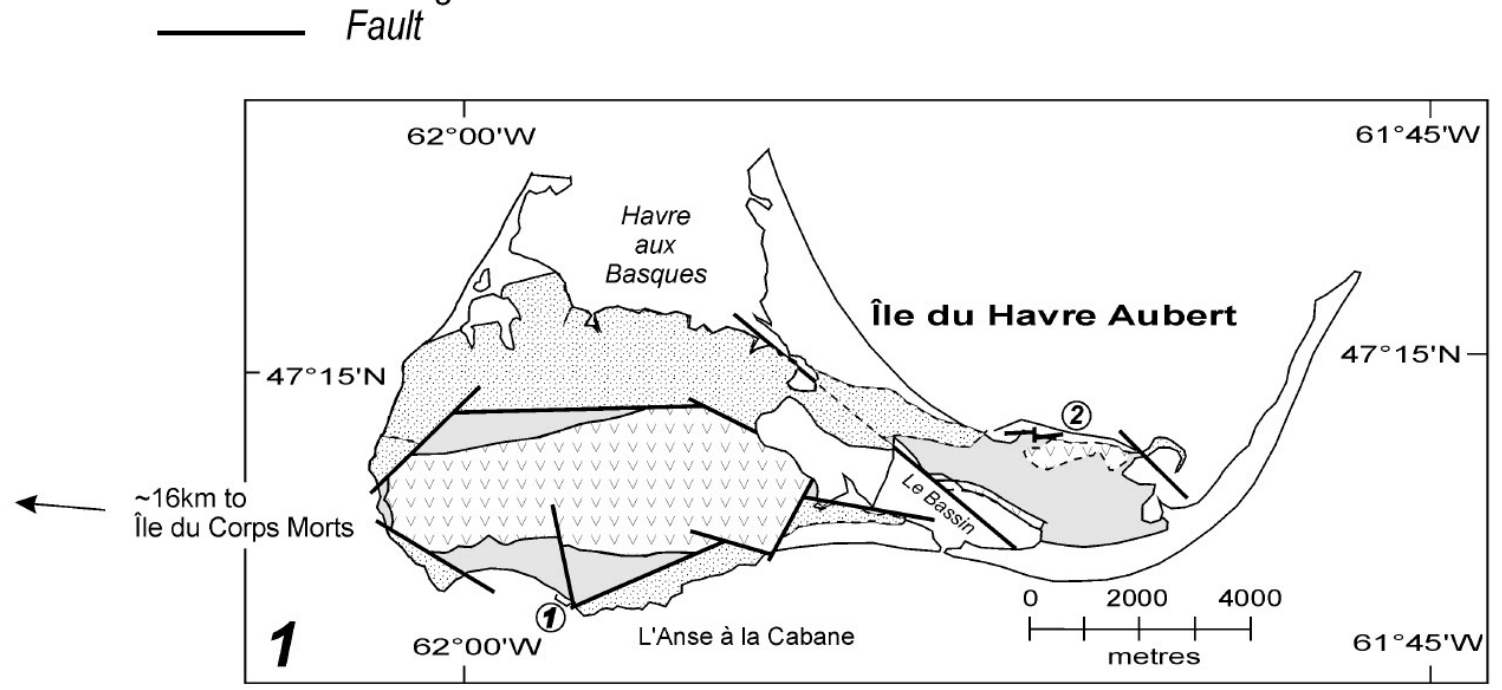

Fig. 3. Geology of the main islands of the Magdalen Islands archipelago, modified after Brisebois (1981); circled numbers indicate the location of measured sections of Fig. 6. Unpatterned areas are recent sand deposits. Volcanic rocks are, in the present study, assigned to the Havre aux Maison Formation of Sanschagrin (1964) although the mapped boundaries are those of the Cap au Diable Formation of Brisebois $(1979,1981)$, here abandoned (see discussion in text). In these southern islands, the Bassin aux Huîtres Member of Sanschagrin (1964) is limited to a single exposure on Île d'Entrée. Numbered maps are those of Fig. 2, each shown at the same scale. Relative positions of each numbered map are shown on Fig. 2. 
BRISBOIS, 1981

PRESENT STUDY

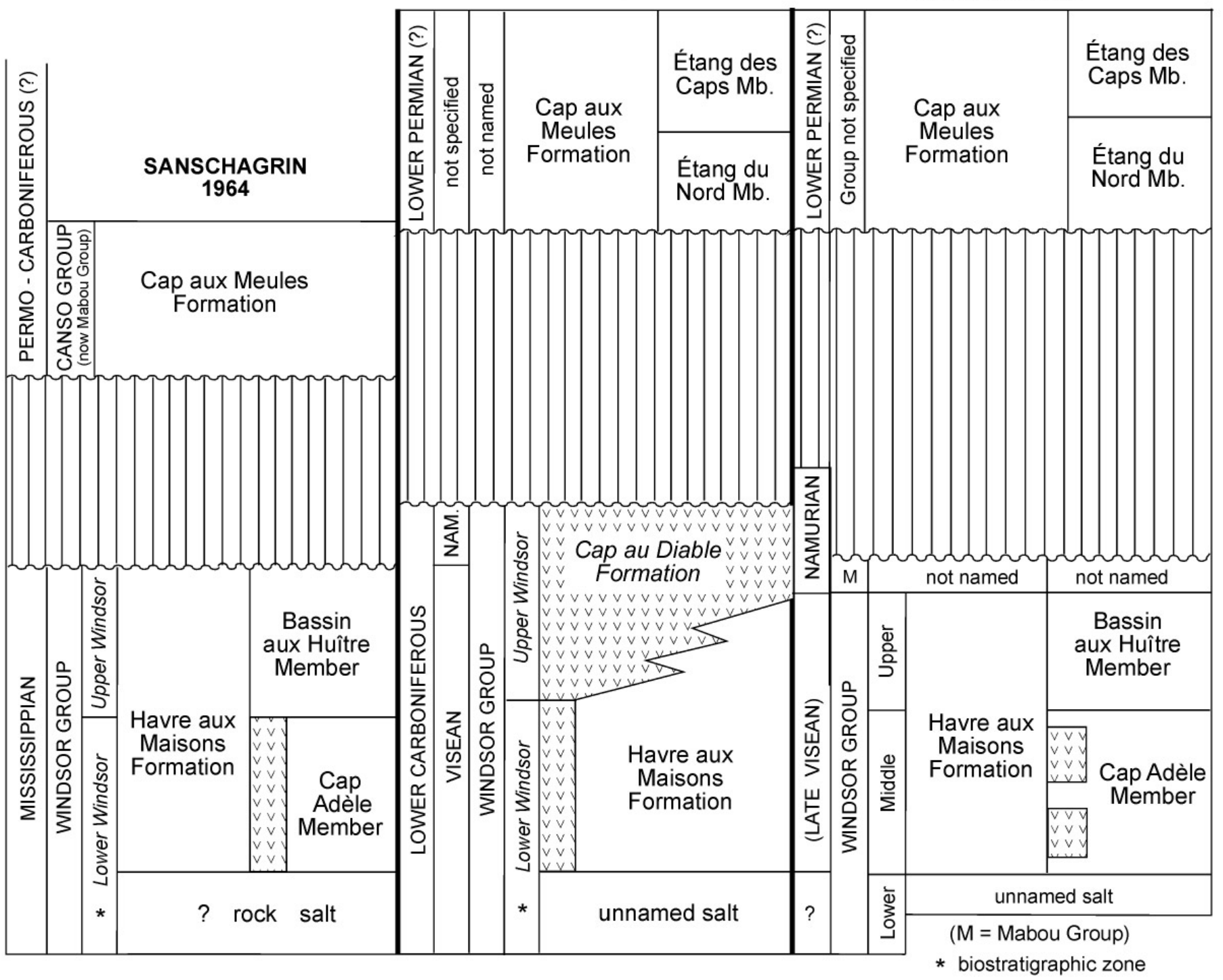

Fig. 4. Lithostratigraphic subdivisions of the Windsor Group and overlying strata on the Magdalen Islands as proposed by Sanschagrin (1964) and Brisebois $(1979,1981)$ and applied in the present work.

and very fine-grained sandstone, characterized by thick beds and large-scale cross-stratification. The thickness of the Étang des Caps Member was estimated at $370 \mathrm{~m}$ by Brisebois (1981, p. 35). Brisebois interpreted the Cap aux Meules Formation to be no older than Stephanian, and suggested a possible Permian age, based on tentative correlation with red strata of that age on Prince Edward Island in the southern part of the Gulf of St. Lawrence.

The chemical affinities of Magdalen Island basalts and their significance to models for Maritimes Basin evolution have been the focus of several research efforts. Barr et al. (1985) addressed the chemistry and petrography of basaltic rocks of the Windsor Group, reporting possible alkaline affinities, but noted the severely altered nature of the volcanic rocks. More recent study of the Magdalen Island basalts (La Flèche et al. 1998) addressed their geochemistry and implications for their origin, and followed Brisebois in assigning the basalts to the highest part of the Windsor Group. La Flèche et al. (1998) reported the presence of geochemically heterogeneous alkalic and tholeiitic basalts. Pe-Piper and Piper (1998) included several samples of Magdalen Island basalt in an assessment of isotopic evidence for mantle and lower crustal sources for Devonian-Carboniferous rocks of the western Maritimes Basin. They concluded that only relatively young, Visean-Westphalian alkalic magmas in this region showed isotopic evidence which might allow input from an asthenospheric plume source. Because of their alteration, these basaltic rocks have not been dated radiometrically. Here, their biostratigraphically constrained stratigraphic position provides some estimate for the timing of basaltic extrusion.

Biostratigraphic studies have considerably expanded the first macrofaunal assessment of Bell (1948). Sanschagrin(1964) 
reported macrofaunas recovered from marine limestone on the Magdalen Islands and followed Bell (1948) in assigning the host strata to lower and upper Windsor Group macrofaunal subzones B, C, D, and E (Fig. 5). Brisebois (1979) and Brisebois and Mamet (1974) reported calcareous foraminiferans and algae from carbonate rocks of the Magdalen Islands with emphasis on the upper parts of the succession. More recent biostratigraphic investigations include an assessment of conodont faunas from marine carbonate rocks of the Magdalen Islands (Plint and von Bitter 1986; von Bitter and Plint 1987), and studies of palynomorphs in Windsor Group strata by Utting (1987). Utting (1987), unlike most recent workers in the archipelago, followed the older lithostratigraphic framework established by Sanschagrin (1964).

Attempts to correlate specific marine carbonate members of the upper Windsor Group on the Magdalen Islands with members recognized in the Windsor Group type area include the combined litho- and biostratigraphic assessment of McCulloch (1973), who studied what he believed to represent a possible correlative of the Kennetcook Limestone Member of Moore (1967; Moore and Ryan 1976, fig. 15), exposed on Île Boudreau. Blakeney (1974) reported on the chemistry and petrography of the most northeasterly exposed carbonate member on Île Boudreau, correlating that carbonate member with the Herbert River Limestone Member (Moore 1967) of the type upper Windsor Group. Blakeney did not address the macrofauna of this carbonate member in detail but alluded to key taxa which suggested correlation with the Herbert River limestone.

All stratigraphic assessment of Magdalen Island exposures are hampered by structural complexities, the apparent lack of unequivocal marker horizons, and uncertainties in even local facing directions. In spite of these difficulties, the present work shows that remnants of the original stratigraphic succession can be documented using both litho- and biostratigraphic data.

\section{WINDSOR AND MABOU GROUP(?) STRATIGRAPHY}

Lithostratigraphically, the Windsor Group can be considered regionally in three parts. At the base of the group, a lower carbonate-sulphate-halite sequence represents a single thick cycle of sedimentation. This sequence is marked at the base by the Macumber Formation (limestone) in Nova Scotia and New Brunswick, and the Ship Cove Formation in southwestern Newfoundland. In basin-margin settings, equivalent strata are typically biohermal and are assigned to the Gays River Formation or local equivalents. Thick anhydrite and salt deposits overlying the Macumber Formation complete this initial transgressive-regressive depositional episode. These rock units are here assigned collectively to the lower Windsor Group

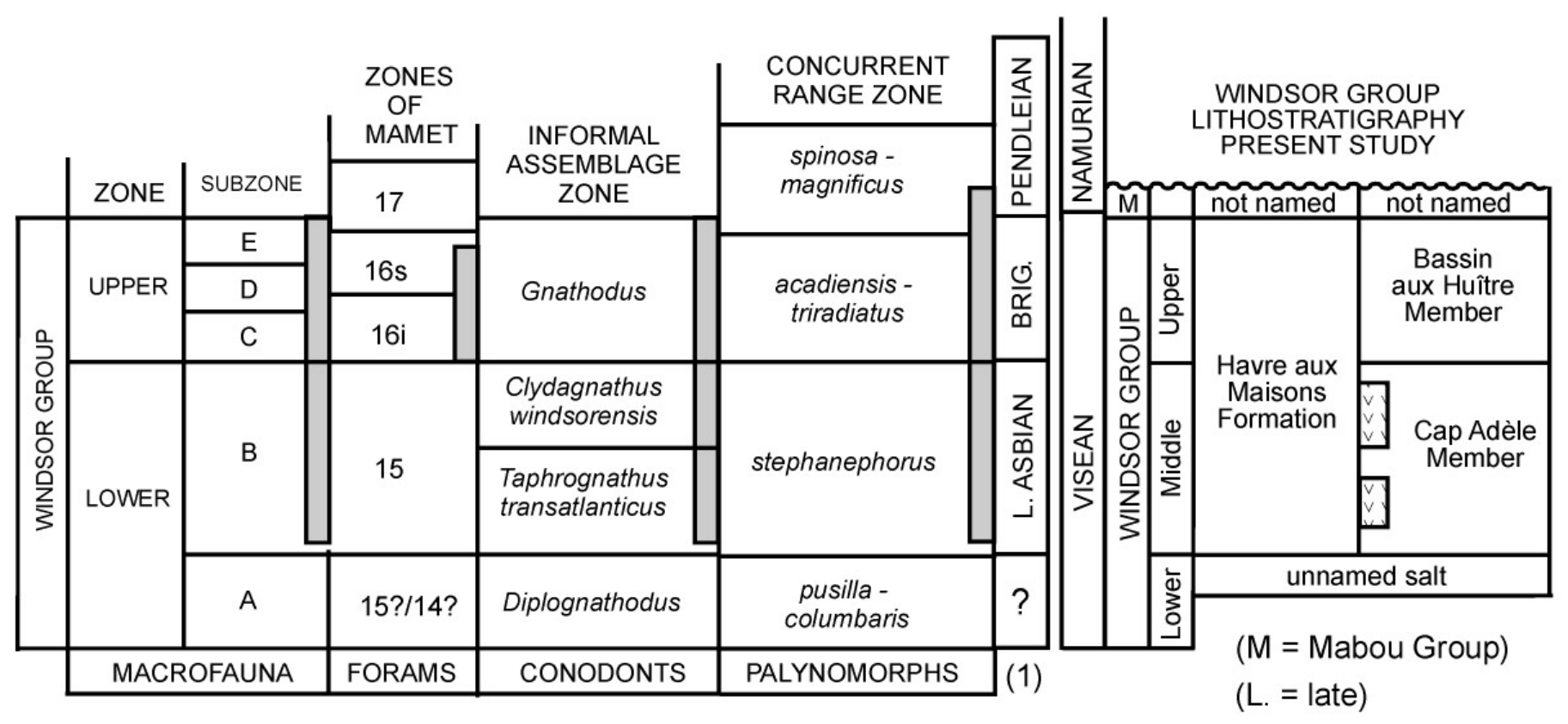

(1) Dinantian stages of George et al., 1976

$($ Brig. $=$ Brigantian $)$

Fig. 5. Biostratigraphic framework for Windsor Group strata on the Magdalen Islands. Macrofaunal zones as defined by Bell (1929); informal conodont zones from Plint and von Bitter (1986); nomenclature for palynomorph Concurrent Range Zones from Utting (1987) as amended by Utting and Giles (2004) and von Bitter et al. (2006); foraminiferal zones of Mamet (1970). Shaded rectangles indicate the interpreted biostratigraphic range for Magdalen Islands strata using all available faunal and miospore data. The lithostratigraphic units recognized in this study are shown to illustrate their suggested biostratigraphic age. 


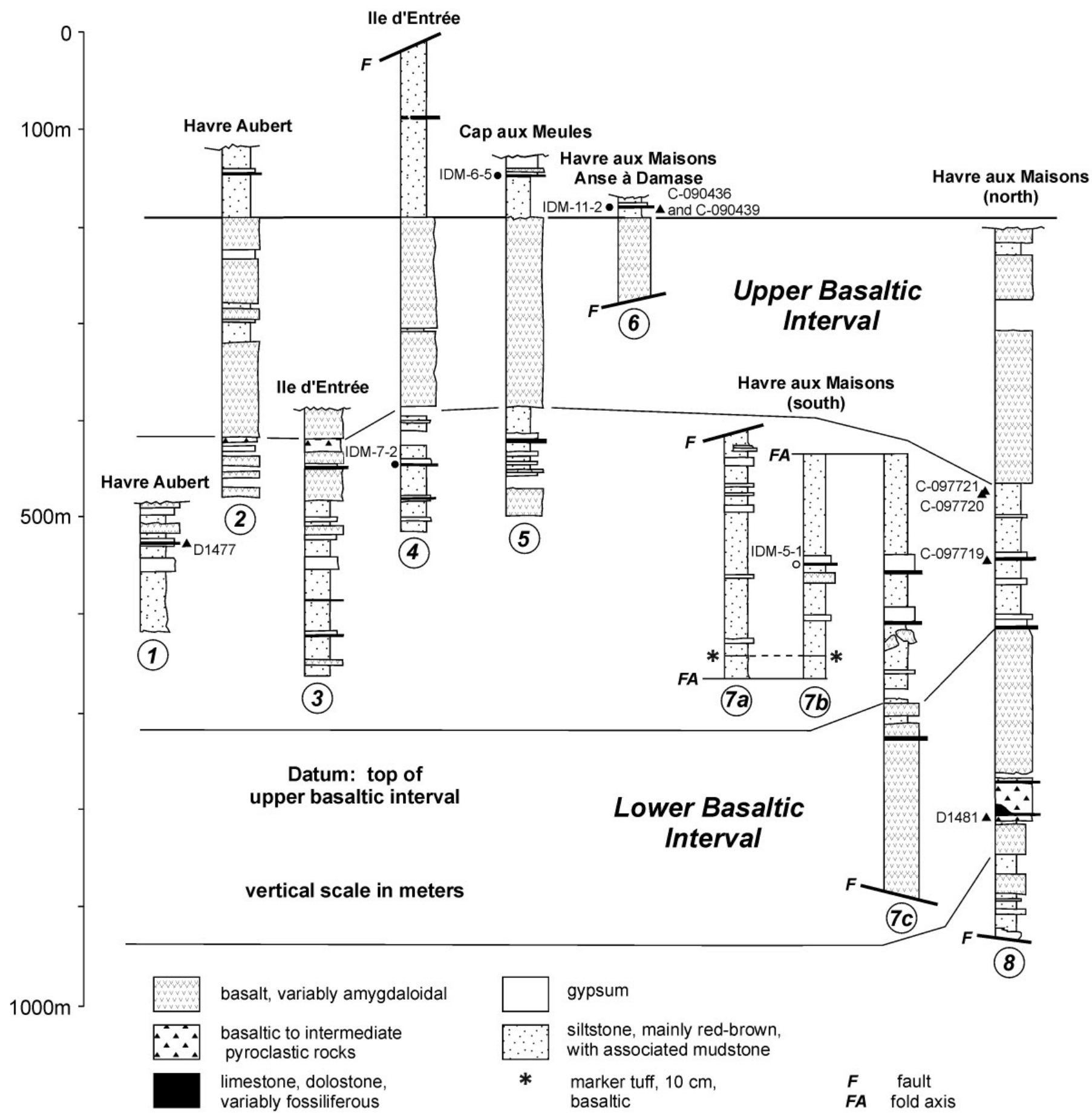

Conodonts recovered by Plint and von Bitter (1986); sample numbers indicated:

- Clydagnathus windsorensis Zone

- Taphrognathus transatlanticus Zone

Miospore sample of Utting (1987)

^ stephanephorus Concurrent Range Zone of Utting and Giles (2004)

Fig. 6. Measured stratigraphic sections representative of the Cap Adèle Member of the Havre aux Maisons Formation. Correlations suggested are consistent with available biostratigraphic data and indicate two main periods of basaltic extrusion. All biostratigraphic data indicate assignment to Bell's (1929) B macrofaunal subzone, to Cycle 2 of Giles (1981) and lithostratigraphically, to the middle Windsor Group. 
(lithostratigraphic). The middle portion of the group comprises numerous repeated cycles of marine carbonates with capping evaporites and non-marine sediments. The upper part of the Windsor Group as described by Moore (1967) is dominated by non-marine strata but contains at least eight marine carbonate members with or without capping evaporites.

The upper Windsor Group of Moore (1967) coincides with the Upper Windsor Zone of Bell (1929) in regional biostratigraphic terminology. The middle Windsor Group as used in this study corresponds to macrofaunal Subzone B of Bell (1929) and the lower Windsor Group (lithostratigraphic) corresponds to Bell's macrofaunal Subzone A. Subzones A and B together comprise the Lower Windsor Zone in generally applied biostratigraphic practice. The inter-relationships between Windsor Group biostratigraphic and lithostratigraphic frameworks are illustrated in Figure 5.

In this paper, italics are used in the text to identify the lower and upper Windsor Group macrofaunal zones of Bell (1929) where this is necessary for the sake of clarity, and to clearly distinguish these zones from the informal lithostratigraphic designations used herein of lower, middle, and upper Windsor Group. Formal Windsor Group lithostratigraphic units applied on the Magdalen Islands and accepted by the present author include the Havre aux Maisons Formation (sensu Sanschagrin 1964), and the Cap Adèle and Bassin aux Huitres members of that formation, again as defined by Sanschagrin (1964). Strata equivalent to the lower part of the Mabou Group in Nova Scotia, here tentatively identified through biostratigraphic assessment using palynological data from Utting (1987), are assigned to that position without additional formal lithostratigraphic terminology. They are represented in a single outcrop.

\section{Lower Windsor Group (unnamed)}

Rock salt which underlies the Magdalen Islands is well documented in drilling reported by Brisebois (1981, fig. 7). In the northern portion of the archipelago, a modern underground mine (Mines Seleine, Fig. 2) utilizes this resource. Drilling has penetrated the salt bodies to depths as great as $900 \mathrm{~m}$ but, because of the diapirically folded nature of the salt, no estimate of true stratigraphic thickness can be made. Thick intersections of anhydrite are typical above the main salt mass in many of the wells, perhaps representing cap rock above diapiric salt. Within the salt bodies, mudstone and mudstone breccias were reported by Brisebois (1981), seemingly interstratified but of uncertain stratigraphic significance, again due to structural complexities. In only two wells were volcanic rocks intersected (Brisebois 1981, fig. 7; holes M16 and M22, Fig. 2). In hole M16, drilled on Havre aux Maisons, volcanic rocks of basaltic composition are associated with mudstone, rock salt and relatively minor anhydrite, with mudstone the predominant lithology. In hole M22, drilled in the vicinity of the salt mine on Grosse Ile in the northern part of the archipelago (Fig. 2), basalt is intercalated with rock salt through an intersected thickness exceeding $100 \mathrm{~m}$, lies near the top of a thick rock salt section, and is itself

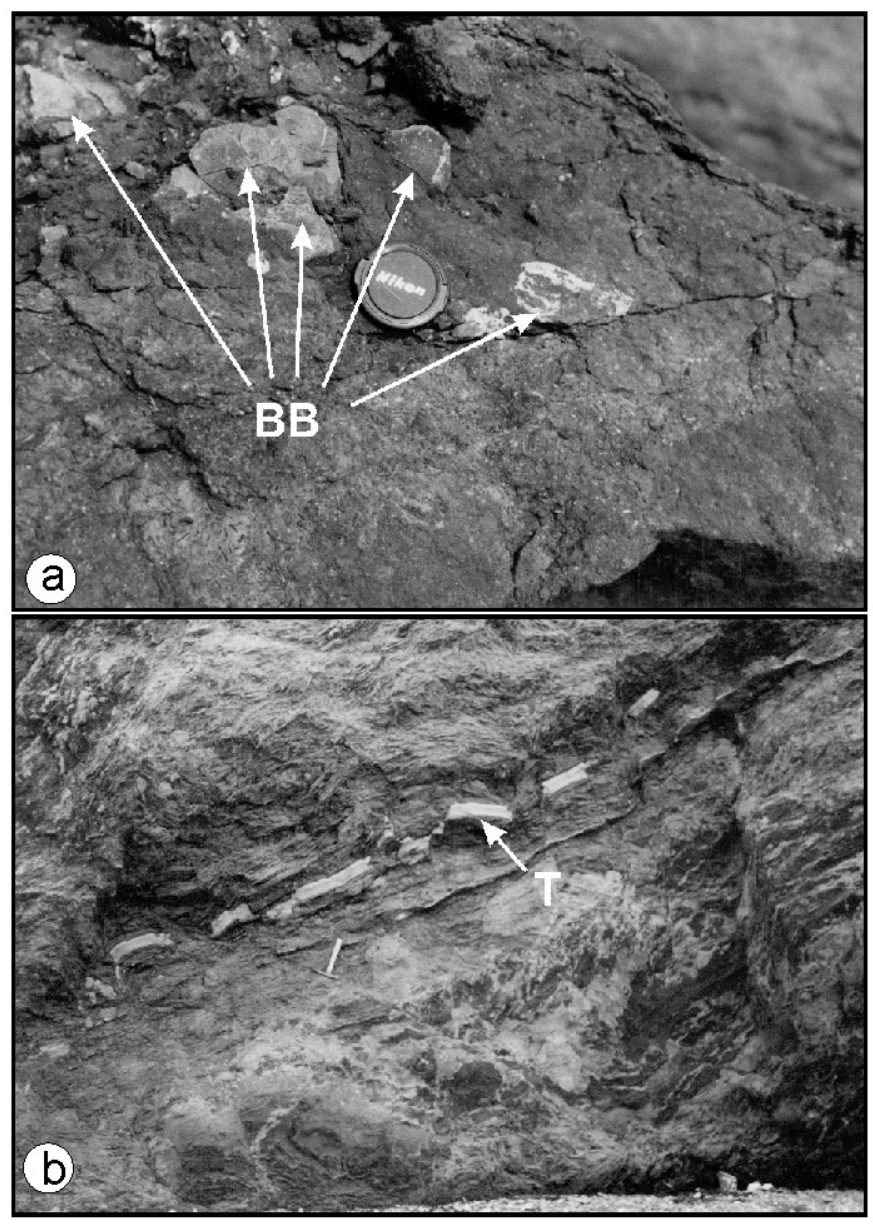

Fig. 7. (a) Basalt blocks in dolomitic carbonate rocks near the base of section 8, Havre aux Maison (Fig. 6). The absence of chilled margins indicates that basalt extrusion predated the marine incursion which resulted in carbonate deposition. Scale is indicated by the camera lens cover, $5.5 \mathrm{~cm}$ in diameter. (b) $10 \mathrm{~cm}$ - thick basaltic tuff marker in coastal cliffs, Havre aux Maison, noted in measured sections $7 \mathrm{a}$ and $7 \mathrm{~b}$ (Fig. 6). Hammer handle is $28 \mathrm{~cm}$ in length. Fault offsets of the tuff marker and pervasive shear in adjacent mudrocks is typical in exposures of the Cap Adèle Member.

capped by mudstone approximately $100 \mathrm{~m}$ in thickness. With these data, it is not possible to suggest stratigraphic relationships with confidence. The salt is presumed to represent lower Windsor Group salt in diapiric structures, following the interpretation of Brisebois (1981). Associated anhydrite, mudstone, and volcanic rocks may represent remnant lower Windsor Group beds, in which case they document volcanism within the upper part of the lower Windsor Group. Alternatively, these rocks may represent tectonic rafts of younger Windsor Group material incorporated in rising salt diapirs. Windsor Group strata beneath these salt beds have not been penetrated by any 
drilling and may be present only at considerable depth beneath the Magdalen Islands.

\section{Middle and upper Windsor Group - Havre aux Maisons Formation (sensu Sanschagrin 1964)}

The Havre aux Maisons Formation includes all strata of the Windsor Group lying above the thick lower Windsor Group salts of Major Cycle 1. The formation includes rocks of both the middle and upper parts of the Windsor Group, each respectively assigned member status. This stratigraphic practice differs from that applied in Nova Scotia to the type Windsor Group at correlative stratigraphic levels, where key carbonate marker bands are assigned member status, and intervening redbeds and evaporites individually unnamed. Each member of the Havre aux Maison Formation is described below.

\section{Middle Windsor Group - Havre aux Maisons Formation - Cap Adèle Member}

The Cap Adèle Member is represented on each of the larger islands of the archipelago, except for the most northerly islands in the group. The member was named by Sanschagrin (1964) for exposures on Havre aux Maisons in the vicinity of Cap Adèle where the member is best exposed (see sections $7 \mathrm{a}, 7 \mathrm{~b}, 7 \mathrm{c}$ and 8, Fig. 6). These exposures were identified by Brisebois (1981, p.8) as the type section of Sanschagrin's Havre aux Maisons Formation, although this designation is not clear in Sanschagrin's original report. The exposures at Cap Adèle are representative of the lithologic assemblages which make up the member, and serve to illustrate as well the nature of deformation encountered in all exposures on the Magdalen Islands. In the absence of a formal type section, they are herein designated the principal reference section for beds of the Cap Adèle Member.

The stratigraphic succession preserved on the shoreline at Cap Adèle comprises basalt, mudstone, gypsum, and variably fossiliferous carbonate rocks. The lowest beds are represented mainly by basalt and associated basaltic tuff, with interbedded biohermal Windsor Group carbonate near the base of the volcanic assemblage (section 8, Fig. 6). The carbonate is rich in brachiopods and bryozoans, and reaches a local thickness of $15 \mathrm{~m}$, but thins rapidly on the biohermal flanks to only 2 $\mathrm{m}$ of thickly bedded dolostone. Fine-grained pyroclastic rocks are in sheared contact with the bioherm at its top and base. No stratification was seen in these tuffs, suggesting subaerial deposition. The biohermal carbonate seems, therefore, to record a relatively short-lived marine incursion, bracketed temporally by subaerial volcanism. The presence of basalt clasts up to 15 $\mathrm{cm}$ in maximum dimension (Fig. 7a) within the thinner facies of the biohermal carbonate low in this section suggests that the basalts are indeed a part of the Windsor Group succession. The basalt clasts lack chilled margins, are totally enclosed within unsheared carbonate host material, and suggest carbonate deposition adjacent to a basaltic substrate which was flooded during marine transgression. The tuffaceous rocks immediately below the biohermal limestone were presumeably part of that volcanic landscape. Derivation of the volcanic clasts within the dolomite from older, pre-Windsor Group basalts is unlikely, given the geographic position of the Magdalen Islands near the present basin centre, and the apparent stratigraphic separation of these middle Windsor Group beds from known older volcanic-bearing successions.

Towards the southwest (section 7c, Fig.6), the succession passes upwards from the main volcanic assemblage through mudstone with one sheared and discontinuous basalt unit and minor gypsum until a relatively thick, steeply dipping gypsum body is exposed in the cliff face. Fossiliferous dolostone is preserved against the gypsum on its northeasterly side, and on the southwestern side, gypsum passes upwards into red mudstone. This relationship is consistent with facing to the southwest, as indicated by the stratigraphic progression from carbonate rock to gypsum to redbeds in that direction. Above this interval, a second gypsum bed is exposed, again underlain by thin highly sheared carbonate rock remnants (and therefore southwesterly facing) and overlain by fine-grained red-brown siltstone and mudstone. Proceeding southwesterly along the shore, two additional gypsum beds occur, separated by mudstone. The most easterly of these sulphate beds is in contact on its western limits with fossiliferous carbonate rocks (section 7b, Fig. 6, sample location IDM-5-1 of Plint and von Bitter 1986), highly sheared and represented by a thickness of only a few tens of centimetres. The position of the carbonate rocks on the westerly side of the gypsum bed suggests facing towards the northeast, indicating possible repetition of this gypsum bed across a fold axis (see FA at tops of sections $7 \mathrm{~b}$ and 7c, Fig. 6) hidden in highly sheared mudstone. Moving still further towards the southwest (and down section), highly deformed basalt and a second relatively thin gypsum interval occur within sheared red-brown mudstone. This gypsum has no associated carbonate rocks to confirm facing direction. A $10 \mathrm{~cm}$ thick basaltic tuff(Figs. $7 \mathrm{~b}$ and 8 ) provides a marker bed within the thick mudstone interval low in section $7 \mathrm{~b}$, underlying the pair of gypsum beds described previously, and underlain in turn, by an impure gypsum/siltstone sequence. To the southwest across the outcrop width of the latter, an identical $10 \mathrm{~cm}$ tuff bed reappears in what is here interpreted as a fold repeat, so that the section again faces southwest (section 7a, Fig.6). Although this tuff is offset by numerous small high-angle faults (Fig. 7b), contacts with the stratigraphically adjacent silts are intact. Thus this tuff confirms that basaltic volcanism was active during middle Windsor Group deposition.

Beginning at the base of Section 8 (Fig. 6) approximately $100 \mathrm{~m}$ beneath the biohermal carbonate, and proceeding northeasterly through the same volcanic sequence which lies at the base of Section 7c, a stratigraphic succession can be determined which passes above the volcanic rocks into interstratified fine-grained redbeds, gypsum, and minor carbonate rocks. These strata are in turn overlain by a second sequence of basaltic rocks. Section 8 suggests that the volcanic rocks of the 
Cap Adèle Member define lower and upper basaltic intervals within the member (Fig. 6), separated by more than $100 \mathrm{~m}$ of siltstone, gypsum, and minor marine carbonate rocks.

Other coastal exposures reveal similar local reversals of facing direction, and in many places, severe shear deformation. Nevertheless, these coastal sections, summarized in Figure 6 , illustrate a first approximation of the lithostratigraphy of the Cap Adèle Member. Two major basaltic intervals can be reasonably postulated on local facing relationships alone. A thickness for the aggregate succession of Figure 6 is estimated, with admitted uncertainties, at approximately 940 $m$. As neither the top nor base of the member can be defined in any of the exposed sections, this estimate of thickness may be considered a minimum. Sanschagrin (1964) estimated the Cap Adèle Member to be approximately $800 \mathrm{~m}$ in thickness. Given the structural complexity and resulting uncertainties in thickness estimates, this $200 \mathrm{~m}$ disparity in thickness estimates is not surprising. The stratigraphic relationships summarized in Figure 6 indicate that as many as eight different carbonate horizons may be represented in these sections. Because they are typically only partially preserved due to extensive shear, no attempt has been made here to describe individual carbonate members in detail, or to suggest more than the most tentative correlations between measured sections. The main utility of the remnant carbonate rocks in stratigraphic reconstruction of the Magdalen Islands succession is the determination of younging directions through their well-known position in minor depositional cycles capped by gypsum (Giles 1981).

Utilizing the palynostratigraphic data provided by Utting (1987), as well as macrofaunal data from Sanschagrin (1964) and Bell (1948), beds of the Cap Adèle Member fall entirely into the Lower Windsor Macrofaunal Zone, specifically Bell's B subzone, or the upper portion of the L. noctuina -K. stephanephorus palynomorph assemblage zone of Utting (1987, NS Zone) (Fig. 5). Utting and Giles (2004) recently documented that Utting's former NS Assemblage Zone could be subdivided, and designated Bell's B subzone palynologically as the Stephanephorus Concurrent Range Zone. Carbonate rocks of the Cap Adèle Member yielded conodonts of both informal assemblage zones recognized within the B macrofaunal subzone by Plint and von Bitter (1986) (Fig. 5). The upper basalt interval of Figure 6 is bracketed above and below by conodont assemblages of the Clydagnathus windsorensis zone. The lower basaltic interval appears to underlie rocks with conodont assemblages of the biostratigraphically older Taphrognathus transatlanticus zone. The distinctive biohermal limestone apparently interbedded with the lower volcanic rocks yielded $\mathrm{B}$ subzone conodonts but could not rigorously be assigned to either of the B subzone conodont zones by Plint and von Bitter (1986). Thus, the designation of two distinct basaltic intervals in Figure 6, suggested by lithostratigraphic arguments, is consistent with the conodont biostratigraphy established by Plint and von Bitter (1986). It is important to note that no carbonate rocks of Sanschagrin's Cap Adèle Member yielded conodonts of the Gnathodus zone of Plint and von Bitter (1986), which they considered to be representative of the upper Windsor Group.
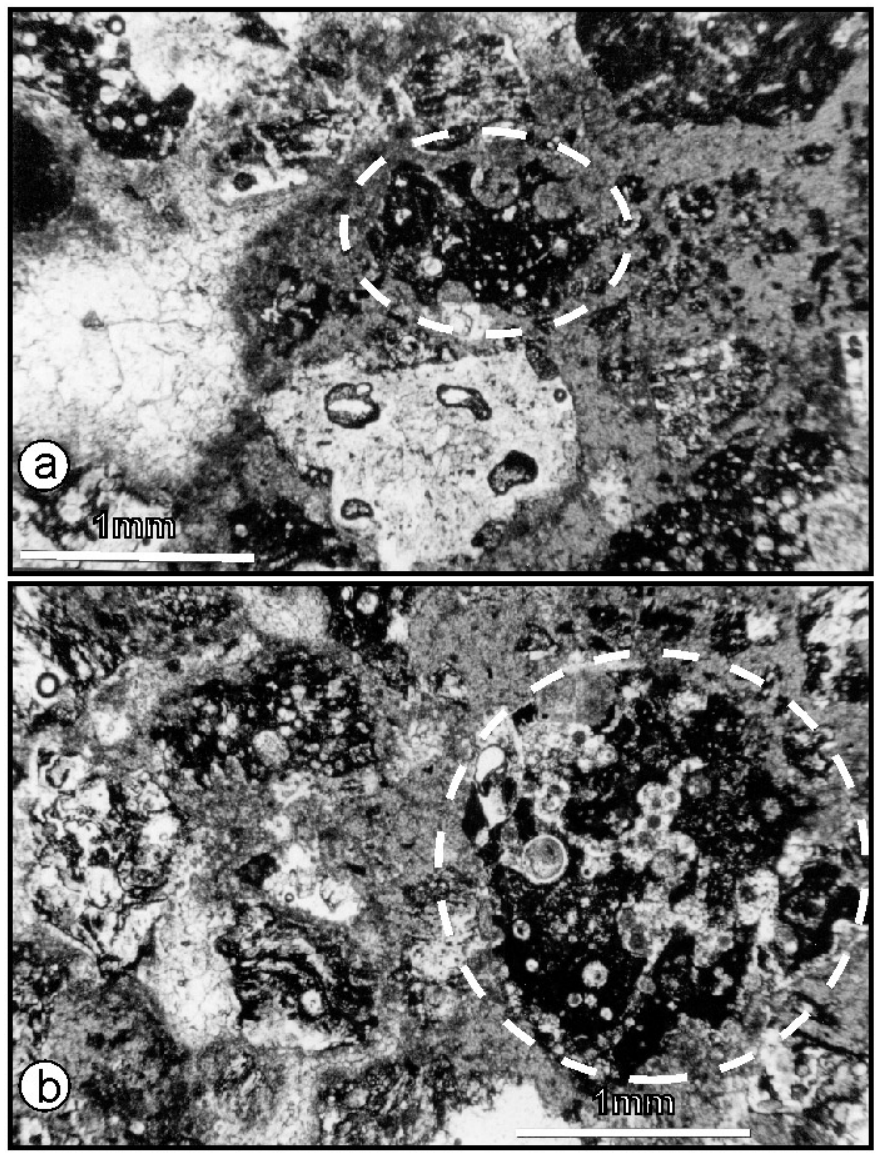

Fig. 8. (a) and (b) Photomicrographs of scoriaceous basaltic tuff marker of Fig. 7 illustrating the vesicular character of selected individual fragments (circumscribed by dashed white line) and their aphanitic dark matrix.

Fig. 9. (Following page) Measured sections of Bassin aux Huîtres Member carbonate rocks exposed on Île Boudreau (sections 1, 2 and 3) and Île d'Entrée (section 4). Map shows the location of upper Windsor beds on the island, situated in the northern part of the archipelago (Fig. 2). Section 1: marine carbonate rocks and marine siltstones considered by McCulloch (1973) to represent the equivalent of the Kennetcook limestone member of the type Windsor Group. Section 2: the most northeasterly exposed carbonate member on Île Boudreau, considered by Blakeney (1974) and by the present author to be equivalent to the Herbert River Limestone Member of Moore (1976) in the Windsor Group type area. The base of this limestone defines the regional boundary between the middle and upper Windsor Group successions, and is here designated the contact between the Cap Adèle and Basin aux Huître members of the Havre aux Maison Formation on the Magdalen Islands, shown here as a dashed line. Section 3: nodular-bedded limestone at western extremity of Bassin aux Huîtres Member exposures on Île Boudreau. Section 4: thickly-bedded, bioturbate dolostone here equated with the Kennetcook limestone member of the type Windsor Group. 

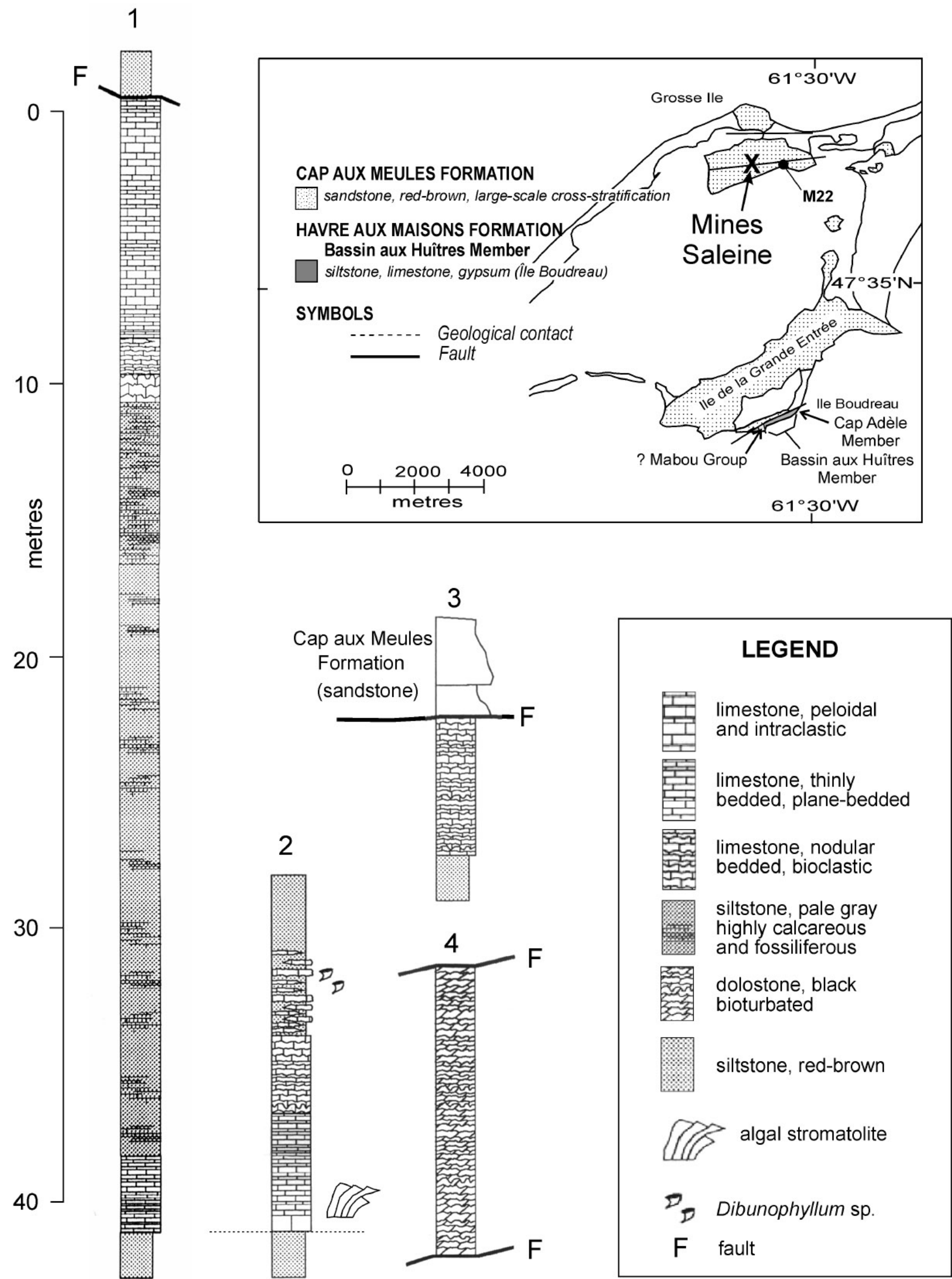
Based on the biostratigraphic assessment of von Bitter et al. (2006), assignment of the middle Windsor Group Cap Adèle Member fauna and palynoflora to Bell's subzone B, or Cycle 2 of Giles (1981) indicates a late Asbian age (Fig. 5). This assignment limits the apparent biostratigraphic 'age' of the volcanic rocks on the Magdalen Islands (see discussion of Bassin aux Huîtres Member).

\section{Upper Windsor Group - Havre aux Maisons Formation - Bassin aux Huîtres Member}

The Bassin aux Huîtres Member is best known from coastal exposures on the southwestern shore of Île Boudreau in the northern part of the archipelago (Figs. 2 and 9). Fossiliferous marine carbonate rocks representing at least three and possibly four cycles of marine transgression and regression can be documented in this coastal section, in association with fine-grained redbeds and minor gypsum. Faults exposed in the cliffs preclude any rigorous stratigraphic reconstruction. Nevertheless, the carbonate rocks are of considerable importance to regional lithostratigraphic assessment.

The lowest carbonate rocks of the Bassin aux Huitres Member are exposed at the northeastern limit of the type section where they overlie approximately $10 \mathrm{~m}$ of red siltstone and fine-grained sandstone. The basal beds of this carbonate unit comprise planar-bedded, peloidal and intraclastic limestone, thinly bedded and rich in siliciclastic detritus. Columnar stromatolites occur a short distance above the base of the carbonate unit, forming aggregate mound-like bodies up to $3 \mathrm{~m}$ in lateral dimension and aproximately $1 \mathrm{~m}$ in height(Fig. 10a). Oncolites are present locally within plane-bedded limestone immediately beneath the stromatolite colonies.

Above the basal planar bedded interval, bed character changes to a distinctive nodular habit with individual beds typically $2-10 \mathrm{~cm}$ in thickness (Fig. 10b). This part of the limestone is micritic and sparsely bioclastic with fine shell debris and scattered crinoid columnal fragments. Calcareous foraminiferans are well preserved in these rocks. These nodular beds form the upper half of the limestone, and pass in turn transitionally upwards into red-brown calcareous siltstone with lensoidal beds of nodular limestone. The nodules diminish in number and in size upwards as siltstone becomes the dominant rock type. In these nodules, rugose corals are an important constituent. It is significant that Dibunophyllum sp. has been reported from this stratigraphic level (Bell 1948; Sanschagrin 1964, locality F4). This genus is known regionally in the Windsor Group only from the Herbert River Limestone Member at the base of the upper Windsor Group of Moore (1967), and Dibunophyllum lambii is considered a guide to identify this stratigraphic level (Moore and Ryan 1976). The presence of this rugose coral taxon suggests correlation of the lowest carbonate unit of the Bassin aux Huitres Member with the Herbert River Limestone Member of the type Windsor Group, as originally proposed by Blakeney (1974). The base of the Herbert River limestone equivalent on Île Boudreau should mark the local base of the upper Windsor Group. Applying regionally consistent lithostratigraphic prac-
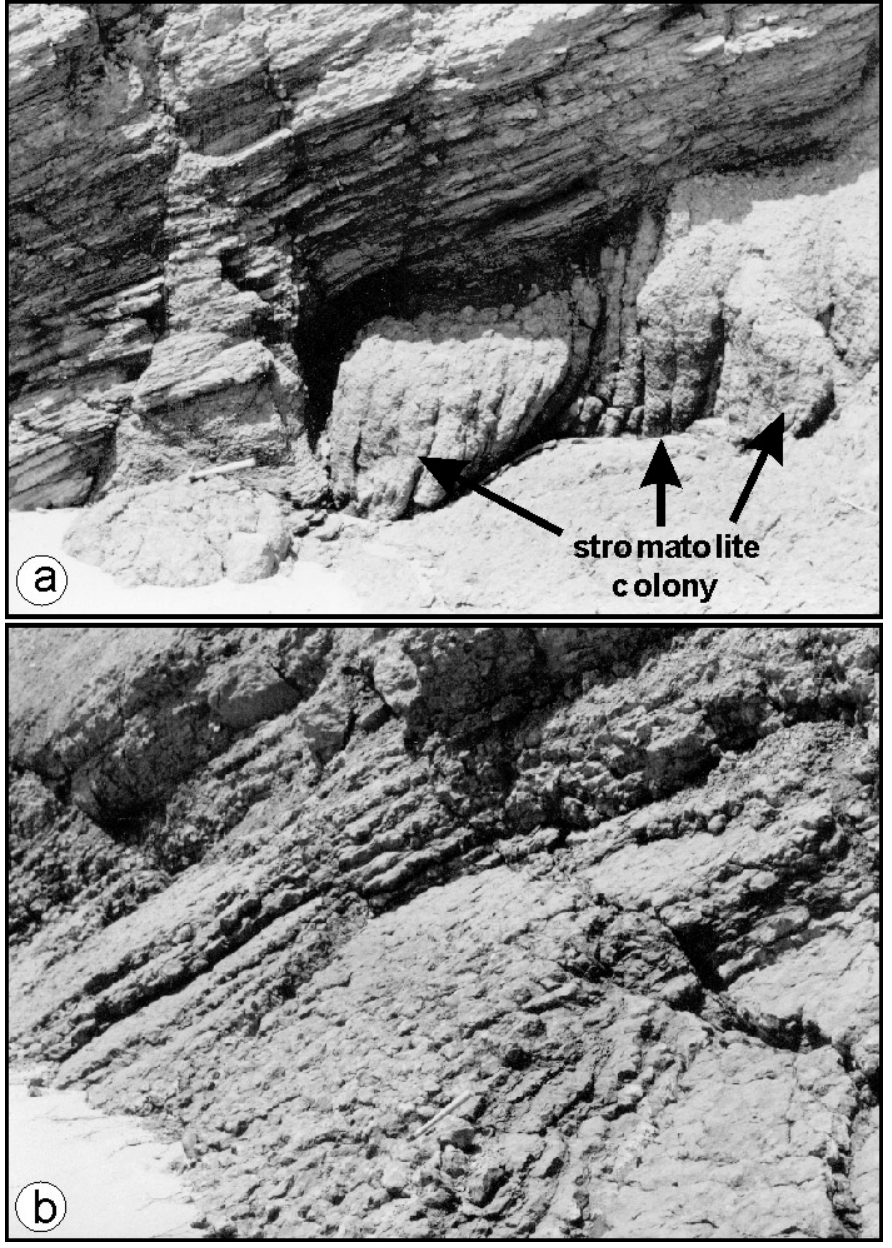

Fig. 10. Herbert River limestone equivalent, section 2, île Boudreau. (a) lowest beds showing plane-bedding and part of an aggregate of club-shaped to cylindrical, inclined stromatolites. (b) main part of the limestone showing irregular bedding surfaces in micritic, thinly bedded facies in which calcareous foraminifera are abundant; red siltstone with nodular lensoidal limestones bearing Dibunophyllum is visible in the upper left of the photograph. $28 \mathrm{~cm}$ hammer handle indicates scale in both photographs.

tice, this interpretation places the defined base of the Bassin aux Huitres Member in the Magdalen Islands succession at the exposed base of this carbonate interval, and the limited thickness of redbeds beneath it are herein, therefore, assigned to the highest beds of the underlying Cap Adèle Member (Figs. 9 and 12).

To the southwest on the shores of Île Boudreau, a second carbonate-rich interval is well exposed, dipping steeply and overturned towards the west. The interval lies above thick red-brown siltstone cut by numerous veinlets of gypsum and containing at least one larger contorted mass of white gypsum, presumed to represent relict bedded evaporites. Limestone forms the base and top part of this interval, whereas grey, highly calcareous siltstone forms the medial portion. A fauna comprising abundant marine molluscs attests to the marine 
origin of this silt-dominated interval, confirmed by the successful recovery of conodonts from the siltstone by Plint and von Bitter (1986). The total thickness of this marine interval is 42 $\mathrm{m}$, including the limestone units at the base and top, and it is presumed to represent deposition resulting from a single cycle of marine transgression and regression. Correlation of this marine interval with Windsor Group strata elsewhere in Atlantic Canada is uncertain, except for its assignment to the upper Windsor Group on the basis of contained conodonts (Plint and von Bitter 1986). McCulloch (1973) suggested that this marine interval represented the equivalent of the Kennetcook Limestone Member (Moore 1967) of the type Windsor Group. Its meager fauna was reported at that stratigraphic level by Moore and Ryan (1976).

Near the western limits of exposure on Île Boudreau, a third marine interval is partially exposed in faulted contact with postWindsor Group strata. The total thickness of limestone at this locality is $5-6 \mathrm{~m}$, comprising thin, nodular beds which are bioclastic and bioturbated throughout the exposure. Although similar to nodular beds of the Herbert River Limestone Member equivalent described above, this thin carbonate lacks the planar-bedded and stromatolitic facies typical of the latter carbonate unit at its base, and is tentatively considered a separate and distinct marine band within the upper member of the Havre aux Maisons Formation.

On Île d'Entrée(Fig. 3), Plint and von Bitter(1986) reported conodonts of their Gnathodus zone from a thick dolomitic carbonate unit, indicating clear upper Windsor Group affinities. The exposed carbonate rocks are oil-stained and almost black in color. With a measured thickness of $13 \mathrm{~m}$, this carbonate interval is dolomitic throughout and heavily bioturbated, and only sparsely fossiliferous. Beds are nodular in character and range from $5-15 \mathrm{~cm}$ in thickness. No internal subdivisions based on bed character or lithology are apparent. Both the apparent top and base are faulted against basalt. Younging direction within the carbonate interval is unknown. Although the fauna is sparse, the writer collected several specimens of the brachiopod Avonia spinocardinata which has been reported only from the Kennetcook Limestone Member of the type upper Windsor Group (Bell 1929; Moore and Ryan 1976). The Kennetcook Limestone Member is the highest marine carbonate known in the type Windsor Group (Moore 1967). In Cape Breton Island and in parts of mainland Nova Scotia, the Kennetcook Limestone Member has been correlated with the so-called E1 limestone (Giles and Boehner 1982) which is characteristically heavily dolomitic and irregularly and thickly bedded due to extensive bioturbation. In light of the contained faunal elements, and its dolomitic, bioturbated nature, the writer suggests that this single exposure on Île d'Entrée represents the local equivalent of the Kennetcook or E1 limestone at the top of the Windsor Group. If this correlation is correct, then the thick marine interval on Île Boudreau assigned by McCulloch (1973) to the same stratigraphic position represents a facies variant of the Île d'Entrée dolostone.

Conodonts, foraminiferans, and palynomorphs recovered from strata of the Bassin aux Huitres Member indicate that these rocks are collectively representative of the upper part of the Windsor Group, confirming Bell's 1948 assignment based on macrofaunal elements (Fig. 5). A latest Visean (Brigantian) to earliest Namurian (Pendleian) age is suggested, following arguments presented by von Bitter et al. (2006). Plint and von Bitter (1986) reported conodonts of their Gnathodus zone (upper Windsor Group) from all of the carbonate rocks sampled on Île Boudreau, and from the dolostone locality on Île d'Entrée. Brisebois and Mamet (1974) and Brisebois (1981) reported well preserved and abundant foraminiferans and calcareous algae in carbonate rocks on Île Boudreau. They noted close similarity with foraminiferal taxa described from the upper part of the Windsor Group in Nova Scotia (Mamet 1970), and reported significant numbers of upper Windsor Group calcareous algae. Brisebois andMamet (1974) assigned these foraminiferal assemblages to Zone 16 and earliest Zone 17 of late Visean (Brigantian; von Bitter et al. 2006) to earliest Namurian age (Fig. 5). Utting (1987) assigned all carbonate-bearing strata from Île Boudreau to his S. acadiensis - K. triradiatus Assemblage Zone which characterizes the upper Windsor Group (Fig. 5). The latter zone is currrently termed the acadiensis - triradiatus Concurrent Range Zone (Utting and Giles 2004).

\section{Mabou Group - unnamed shale and mudstone}

At the single locality on western Île Boudreau, tightly folded grey shale and mudstone with abundant salt-crystal casts, interbedded with red and pale-green mudstone and heavily veined with gypsum (Fig. 11), crop out on the coastal cliff. No macrofauna was seen. All contacts with this local succession are faults. These strata are here assigned to the Mabou Group because regionally, grey shale is not typical of the Windsor Group except where intimately associated with marine carbonate rocks. In the latter case, Windsor Group grey shales are often themselves demonstrably marine on the basis of contained macrofauna. Association of Mabou Group grey shale and mudstone with gypsum and halite is common in the subsurface within the Hastings Formation (Crawford 1995) at the base of the group. Without associated marine carbonate rocks, the exposures on Île Boudreau are thus most similar to the lowest part of the Mabou Group. Assignment to the Mabou Group, although tentative, is consistent with regional depositional patterns in which grey shale and mudstone with intercalated evaporites normally follow the highest Windsor Group marine carbonate, which itself appears to be locally represented on the Magdalen Islands.

Utting (1987) recognized G. spinosa - I. magnificus assemblages in grey shale found in limited exposures on Île Boudreau (SM Assemblage Zone in Utting 1987; amended to spinosa - magnificus Concurrent Range Zone in Utting and Giles 2004). The latter concurrent range zone is typical of the Hastings Formation (Belt 1965; Crawford 1995; Hamblin 2001) of the Mabou Group, immediately overlying the highest marine carbonate rocks of the Windsor Group in much of eastern and southern Nova Scotia. This assemblage zone has 
more recently been documented in the uppermost Windsor and Codroy groups (Utting and Giles 2004). The shale which yielded SM spores on Île Boudreau could therefore be assigned to either the uppermost Windsor Group or to the Mabou Group on biostratigraphic evidence. With some reservations due to the limited exposures, this shale has been assigned here to the Mabou Group and very probably the lowest part of that group.

\section{DISCUSSION}

The evidence for assignment of the volcanic rocks of the Magdalen Islands succession to the Windsor Group is unequivocal. Blocks of basalt incorporated within bedded marine limestone, and more definitively the interstratification of basaltic tuff with fine-grained siltstone and mudstone of the biostratigraphically dated middle Windsor Group succession indicate clearly that volcanism was a part of the depositional history of the Windsor Group in the archipelago. The restriction of volcanic rocks to the middle part of the Windsor Group, i.e., the lower member of the Havre aux Maisons Formation, contrasts with the previous interpretation of Brisebois (1981) and warrants discussion here.

Simply stated, Magdalen Island volcanic rocks occur in stratigraphic continuity only with strata assigned here to the Cap Adèle Member. In the Île Boudreau section, where marine strata are largely equivalent to beds of the upper Windsor Group, no volcanic rocks are seen. On Île d'Entrée, volcanic rocks are extensive but are not in stratigraphic contact with fault-bound upper Windsor strata. Furthermore, on that island, beds which appear to be in stratigraphic contact with basalts were assigned biostratigraphically (Plint and von Bitter 1986) to the lower portion of the Havre aux Maisons Formation, the Cap Adèle Member of this study. Although there is no a priori reason to suggest that the volcanic rocks could not occur throughout the Windsor Group succession, data presently available cannot confirm this broader distribution. Basaltic rocks sparsely represented within the diapiric lower Windsor Group salt in boreholes M16 and M22 have uncertain stratigraphic validity. Thus, the writer's assessment of lithostratigraphic position (Figs. 4 and 6) is the most cautious but the best supported hypothesis, and is in agreement with the original interpretations of both Bell (1948) and Sanschagrin (1964). The rationale for the Cap au Diable Formation of Brisebois $(1979,1981)$ as a major volcanic-bearing rock unit, equivalent in age to the upper Windsor Group, cannot be supported with present data and that term is here abandoned (Fig. 4). The stratigraphy of the Cap Adèle Member, which is represented by the measured sections of Figure 6, suggests that basalts can be assigned to two principal horizons. Because these sections are not constrained at the top or base by recognized contacts, the member could contain basaltic rocks at additional horizons.

The occurrence of basalt within the late Visean succession in the archipelago is unique in rocks of this age in eastern Canada, although basalts have been reported from Tournaisian and
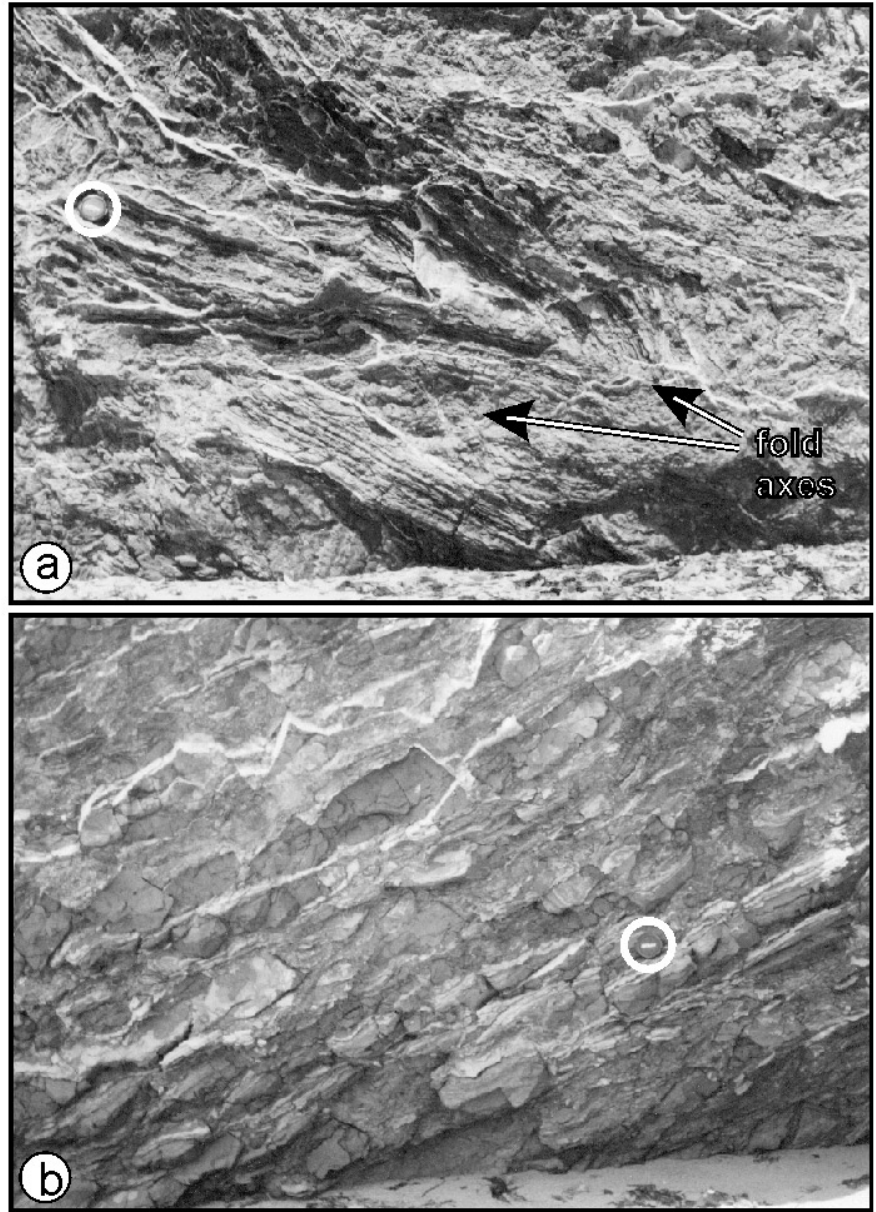

Fig. 11. Mabou Group (?) near the western limit of exposure, île Boudreau. (a) tightly folded grey mudrock; pervasive vein material is satin-spar gypsum. (b) pale greygreen, partially laminated mudrock, interbedded with red-brown, typically massive mudrock. Note the shear deformation illustrated by boudins and incipient boudins, many of which show rotation during shear. Camera lens cover $(5.5 \mathrm{~cm}$ diameter $)$ indicates scale in both photographs.

Fig. 12. (Following page) Composite stratigraphy of the Windsor Group on the Magdalen Islands compared with a thick saline Windsor Group succession from central Cape Breton Island, Nova Scotia. Correlation points are derived from the present work and are very approximate except for the Herbert River limestone marker horizon. Thickness indicated for the Magdalen Islands section is at best a conservative estimate. The total thickness of the Basin aux Huître member has been arbitrarily assigned to make the correlative lower and upper Windsor Group intervals proportional to the Cape Breton Island succession when the geographically and stratigraphically unique basalt of the Cap Adèle Member is disregarded. 


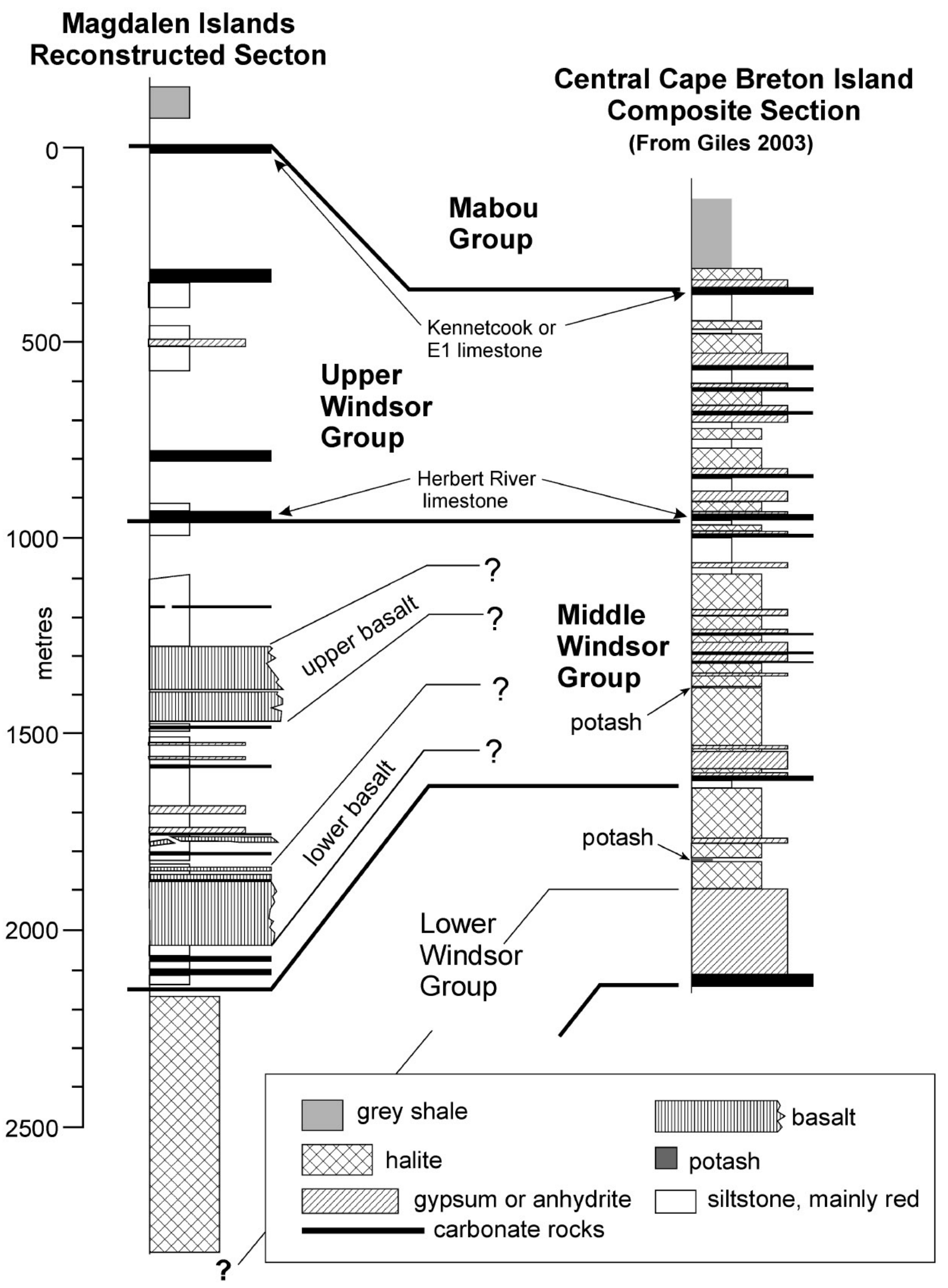


Namurian Maritimes Basin strata in New Brunswick (Fyffe and Barr 1986) and from mid-Visean rocks of Cape Breton Island (Barr et al. 1994). Within the Gulf of St. Lawrence, in the broad vicinity of the Magdalen Islands, several deep hydrocarbon exploration wells have penetrated the Windsor Group succession. The Brion Island well, drilled approximately $20 \mathrm{~km}$ north of the main archipelago, failed to intersect any volcanic rocks in a relatively thick section of evaporite, shale, and minor carbonate rocks biostratigraphically identified as Windsor Group equivalents (Giles and Utting 2003). The Shell - Amoco Cap Rouge F-52 well, drilled south of the Magdalen Islands in the Gulf of St. Lawrence, drilled a complete section of the Windsor Group (Giles and Utting 2001) without volcanic rocks. The Bradelle L-49 well, drilled west of the Magdalen Islands, intersected only a thin interval of marine carbonate rocks equivalent to the Windsor Group (Giles and Utting 2003), and likewise failed to provide documentation of any basaltic rocks of comparable age.

The age of the basaltic rocks is biostratigraphically indicated but not presently substantiated by any radiometric dates. Von Bitter et al. (2006) assigned strata of the middle part of the Windsor Group, including Bell's B subzone and Cycle 2 of Giles (1981), to the late Asbian substage of George et al. (1976). The correlations suggested here likewise assign the basaltic rocks of the Magdalen Islands Windsor Group to the late Asbian. Time Scale B of Menning et al. (2000), the most recently published attempt to summarize absolute ages for the British Dinantian substages, estimates that the Asbian extends from 331 to 334.5 $\mathrm{Ma}$, which provides some tentative constraint on the absolute age of the Magdalen Island basalt. The late Asbian should be represented by the younger part of the Asbian (total) range, perhaps from 331 to $333 \mathrm{Ma}$. Basaltic lavas and tuffs of Asbian age have been noted in southwestern Ireland in the Limerick syncline (Somerville et al. 1992). Clays with K-bentonitic compositions containing igneous-derived accessory minerals were noted from eight discrete thin levels within latest Asbian strata in the vicinity of the Askrigg platform in north-central England by Walkden (1979) who also noted that similar K-bentonite also occurs near the top of the Brigantian substage. The presence of Asbian K-bentonitic clay horizons in North Wales was reported by Somerville (1979).

Rees et al. (1996) described Asbian basaltic tuffs in a deep borehole at Apedale in central England and linked this volcanic activity to much more widespread volcanism. They attributed this volcanism to active late Asbian and early Brigantian rifting which affected much of northwestern Europe. The Apedale volcanic centre was described as larger than most of comparable age in central England, with tuffaceous deposits ranging from 100s - 1000 $\mathrm{m}$ in thickness, covering an estimated and very modest $100 \mathrm{~km}^{2}$. The Magdalen Islands basaltic flows and tuffs are comparable in presently documented (minimum) lateral extent and estimated thickness to Asbian volcanic rocks described in the Apedale borehole. If these rocks represent an analogous centre of Asbian volcanic activity in eastern Canada, the extent of the local basaltic rocks could be likewise very limited. However, other similar centres of volcanic activity could easily escape recognition in the submarine portions of the Maritimes Basin beneath the Gulf of St. Lawrence.

Windsor Group rocks on the Magdalen Islands occur in easterly to east-northeasterly trending fault-bound horst blocks (Brisebois 1981). Ryan and Boehner (1994) showed that Windsor Group salt movements in the Cumberland Basin of Nova Scotia often exploited major fault systems, resulting in linear faulted anticlinal structures, cored by Windsor Group salt in the subsurface. A similar mechanism might explain the elongate salt-cored horst blocks of the Magdalen Islands. PePiper and Piper (1998) noted that alkalic magmas of Visean to Westphalian age in the western Maritimes Basin (or the Magdalen Basin) ascended along crustal-scale faults. If the Magdalen Island horst blocks are the surface manifestation of deeper crustal faults, the salt-basalt association would be consistent with igneous intrusion ascending the same deepseated faults which subsequently focused diapiric salt movements. The salt-basalt association suggests that potential field magnetic and gravity data might be useful in tracing the major structures of the Magdalen Islands offshore into the adjacent Gulf of St. Lawrence.

Within the Bassin aux Huitres Member of the Havre aux Maisons Formation, carbonate members equivalent to both the Herbert River Limestone Member and, less confidently, the Kennetcook (or E1) Limestone Member can be recognized. These members in the type Windsor Group mark the base and top, respectively, of the upper part of the Windsor Group (Moore 1967; Giles and Boehner 1982). Two additional upper Windsor Group carbonate members are exposed on Ile Boudreau, but their lithostratigraphic correlation with type Windsor Group members is not certain. It is of particular importance that both the lowest and the highest carbonate members of the upper Windsor Group appear to be represented in exposures on the Magdalen Islands. Their presence, overlying a thick succession of middle Windsor Group strata also containing a significant number of marine carbonate intervals, suggests that a large and relatively complete portion of the Windsor Group is represented. This situation contrasts with sections in northwestern Nova Scotia and southeastern New Brunswick where upper Windsor Group carbonate beds are absent (Ryan and Boehner 1994) and middle Windsor Group marine bands dramatically reduced in number, possibly represented only in the lowest portion of the middle Windsor. The Magdalen Islands exposures are most comparable with the complete Windsor Group succession documented in the type area and in the Shubenacadie and Musquodoboit Basins of southern Nova Scotia, and throughout Cape Breton Island, in terms of stratigraphic completeness and longevity of marine influence (Fig. 12).

\section{CONCLUSIONS}

In spite of structural complexity, vestiges of the Late Visean Windsor Group succession can be documented on the Magdalen Islands. Lower Windsor Group strata are represented by thick salt deposits which underlie the islands, known 
only from the subsurface. The middle Windsor Group is represented by a total estimated thickness (reconstructed) approaching $1200 \mathrm{~m}$, comprising gypsum, red and lessor grey siltstone, marine carbonate rocks, and volcanic rocks. The latter include both basaltic flows and basaltic volcaniclastic rocks, with significant thicknesses of basalt concentrated at two distinct levels within the middle Windsor Group. The basaltic rocks are of late Asbian age. Strata of the upper Windsor Group are more limited in their distribution in coastal exposures, but appear to include local representatives of key marine strata of the type upper Windsor Group, including the stratigraphically highest beds. No reliable estimate of total thickness for the upper Windsor Group on the Magdalen Islands can be made. Volcanic rocks cannot be demonstrated to interbed with strata of the upper Windsor Group on the Magdalen Islands. The Cap au Diable Formation, erected as a volcanic-dominated rock unit of the upper Windsor Group on the Magdalen Islands, is therefore abandoned. In its degree of completeness as indicated by the preservation of marine marker horizons, the Magdalen Islands succession compares best with the Windsor Group in southern and eastern Nova Scotia, including Cape Breton Island.

\section{ACKNOWLEDGEMENTS}

Appreciation is expressed to John Utting and Peter H. von Bitter for numerous discussions of regional Visean biostratigraphy and for their efforts to keep me on solid footing. David Piper and Marie-Claude Williamson at Geological Survey of Canada (Atlantic) reviewed early versions of the manuscript and made many helpful suggestions for improvement. Gary Grant at Geological Survey of Canada (Atlantic) assisted with several of the figures. Thanks are due for the efforts of journal reviewers Martin Gibling and Robert Ryan who, on behalf of the journal, made many suggestions which materially improved the manuscript. This work comprises Contribution Number 20080056 of the Earth Sciences Sector, Natural Resources Canada.

\section{REFERENCES}

ALcock, F.J. 1941. The Magdalen Islands, their geology and mineral deposits. Transactions of the Canadian Institute of Mining and Metallurgy, 44, pp. 623-649.

Barr, S.M., Brisebois, D., ANd Macdonald, A.S. 1985. Carboniferous volcanic rocks of the Magdalen Islands, Gulf of St. Lawrence. Canadian Journal of Earth Sciences, 22, pp. 1679-1688.

Barr, S.M., Grammatikopoulos, A.L., ANd DunNing, G.R. 1994. Early Carboniferous gabbro and basalt in the St. Peters area, southern Cape Breton Island, Nova Scotia. Atlantic Geology, 30, pp. 247-258.

Bell, W.A. 1929. Horton - Windsor District, Nova Scotia. Geological Survey of Canada, Memoir 155, 268 p.
BELL, W.A. 1948. Magdalen Islands. Geological Survey of Canada. Unpublished manuscript, $15 \mathrm{p}$.

BELT, E.S. 1965. Stratigraphy and paleogeography of Mabou Group and related Middle Carboniferous facies, Nova Scotia, Canada. Geological Society of America Bulletin, 76, pp. 777-802.

BlaKENEY, R.S. 1974. The geochemistry and stratigraphy of the Herbert River Limestone Member of the Mississippian Windsor Group in Atlantic Canada. Unpublished M.Sc. thesis, Acadia University, Wolfville Nova Scotia, 221 p.

BRISEBOIs, D. 1979. Stratigraphie du Permo-Carbonifère des îles de la Madeleine. Non publié Thèse de doctorat,Université de Montréal, Montréal, Québec, 274 p.

BRISEBOIs, D. 1981. Lithostratigraphie des strates Permo-Carbonifères de l'archipel des îles de la Madeleine. Ministère de l'Énergie et des Ressources du Québec, 48 p.

Brisebois, D., And Mamet, B. 1974. Sur la présence des couches de passage du Viséan au Namurian dans les îles de la Madeleine. Compte-rendu sommaire de la Société Géologique de France, pp. 60-62.

Clarke, J.M. 1911. Observations on the Magdalen Islands. New York State Museum, Bulletin 149, pp. 134-156.

CRAWFORD, T.L. 1995. Carbonates and associated sedimentary rocks of the Upper Visean to Namurian Mabou group, Cape Breton Island, Nova Scotia; evidence for lacustrine deposition. Atlantic Geology, 31, pp. 167-182.

Durling, P., AND Marillier, F. 1993. Tectonic setting of Middle Devonian to Lower Carboniferous rocks in the Magdalen Basin. Atlantic Geology, 29, pp. 199-217.

FyfFe, L.R., AND BARR, S.M. 1986. Petrochemistry and tectonic significance of Carboniferous volcanic rocks in New Brunswick. Canadian Journal of Earth Sciences, 23, pp. 1243-1256.

GiLES, P.S. 1981. Major transgressive-regressive cycles in middle to late Visean rocks of Nova Scotia. Nova Scotia Department of Mines and Energy, Paper 81-2, 27 p.

GILES, P.S. 2003. Stratigraphy and structure of the Malagawatch salt deposit - Windsor Group, central Cape Breton Island, Nova Scotia. Geological Survey of Canada, Open File 1531.

Giles, P.S., ANd Boehner, R.C. 1982. Subdivision and regional correlation of strata of the upper Windsor Group, Cape Breton Island and central Nova Scotia. In Mineral Resources Division, Report of Activities 1981, Nova Scotia Department of Mines and Energy, Report 82-1, pp. 69-78.

Giles P.S., AND UtTing. J. 2001. SHELL - AMOCO Cap Rouge F-52, Gulf of St. Lawrence, eastern Canada. Geological Survey of Canada, Open File 3204.

GiLEs, P.S., AND UtTing, J. 2003. Carboniferous stratigraphy of the Bradelle L-49 and Brion Island wells, central and northern Gulf of St. Lawrence, Maritimes Basin, eastern Canada. Geological Survey of Canada, Open File 1679.

George, T.N., Johnson, G.A.L., Mitchell, M., Prentice, J.E., Ramsвottom, W.H.G., Sevastopulo, G.D., AND WiLson, R.B. 1976. A correlation of Dinantian rocks in the 
British Isles. Special Report 7, Geological Society (London), $87 \mathrm{p}$.

Hamblin, A.P. 2001. Stratigraphy, sedimentology, tectonics and resource potential of the Lower Carboniferous Mabou Group, Nova Scotia. Geological Survey of Canada, Bulletin $568,166 \mathrm{p}$.

Howie, R.D. 1988. Upper Paleozoic evaporites of southeastern Canada. Geological Survey of Canada, Bulletin 380, $120 \mathrm{p}$.

La Flèche, M.R., Camiré, G. A., And Jenner, G.A. 1998. Geochemistry of post-Acadian, Carboniferous continental intraplate basalts from the Maritimes Basin, Magdalen Islands, Quebec, Canada. Chemical Geology, 148, pp. 115-136.

Mamet, B.L. 1970. Carbonate microfacies of the Windsor Group (Carboniferous), Nova Scotia and New Brunswick. Geological Survey of Canada, Paper 70-21, 121 p.

Menning, M., Weyer, D., Drozdzewski, G., van Amerom, H.W.J., AND WENDT, I. 2000. A Carboniferous Time Scale 2000: discussion and use of geological parameters as time indicators from central and western Europe. Geologisches Jahrbuch, A 156, pp. 3-44.

McCulLoch, P.D. 1973. Biostratigraphy of the Upper Mississippian Kennetcook Limestone in the Fundy Epieugeosyncline, Maritime Provinces. Unpublished M.Sc. thesis, Acadia University, Wolfville, Nova Scotia, 178 p.

Moore, R.G. 1967. Lithostratigraphic units in the upper part of the Windsor Group, Minas Sub-basin, Nova Scotia. In collected papers on geology of the Atlantic Region. Edited by E.R.W. Neale and H. Williams. Geological Association of Canada, Special Paper 4, pp. 245-266.

Moore, R.G., AND Ryan, R.J. 1976. Guide to the invertebrate fauna of the Windsor Group in Atlantic Canada. Nova Scotia Department of Mines and Energy, Paper 76-5, 75 p.

Pe-Piper, G., And Piper, D.J.W. 1998. Geochemical evolution of Devonian-Carboniferous igneous rocks of the Magdalen basin, Eastern Canada: $\mathrm{Pb}$ - and $\mathrm{Nd}$-isotope evidence for mantle and lower crustal sources. Canadian Journal of Earth Sciences, 35, pp. 201-221.

Plint, H.A., AND von BitTer, P.H. 1986. Windsor Group (Lower Carboniferous) conodont biostratigraphy and palaeoecology, Magdalen Islands, Quebec, Canada. Canadian Journal of Earth Sciences, 23, pp. 439-453.

Rees, J.G., Cornwell, J.D., Dabek, Z.K., And Merriman, R.J. 1996. The Apedale tuffs, North Staffordshire: Probable remnants of a late Asbian/Brigantian volcanic centre. In Recent Advances in Lower Carboniferous Geology. Edited by P. Strogen, I.D. Somerville and G.L. Jones. Geological Society, Special Publication 107, pp. 345-357.
Ryan, R.J., AND Boehner, R.C. 1994. Geology of the Cumberland Basin, Cumberland, Colchester and Pictou counties, Nova Scotia. Nova Scotia Department of Natural Resources, Memoir 10, 222 p.

Ryan, R.J., Boehner, R.C., and Calder, J.H. 1991. Lithostratigraphic revision of the Upper Carboniferous to Lower Permian strata in the Cumberland Basin, Nova Scotia, and the regional implications for the Maritimes Ba$\sin$ in Atlantic Canada. Bulletin of the Canadian Society of Petroleum Geologists, 39, pp. 289-314.

SAnschagrin, R. 1964. Les îles de la Madeleine. Ministère des Richesses Naturelles du Québec, rapport géologique $106,59 \mathrm{p}$.

SomerviLLE, I.M. 1979. Minor sedimentary cyclicity in late Asbian (upper D1) limestones in the Llangollen district of North Wales. Proceedings of the Yorkshire Geological Society, 42, pp. 317-342.

Somerville, I.M., Strogen, P., And Jones, G.L. 1992. Biostratigraphy of Dinantian limestones and associated volcanic rocks in the Limerick Syncline, Ireland. Geological Journal, 27, pp. 201-220.

Utting, J. 1987. Palynology of the Lower Carboniferous Windsor Group and Windsor-Canso boundary beds of Nova Scotia, and their equivalents in Quebec, New Brunswick and Newfoundland. Geological Survey of Canada, Bulletin $374,93 \mathrm{p}$.

UtTing, J., AND GiLEs, P.S. 2004. Biostratigraphical implications of new palynological data from the Mississippian of Newfoundland and Nova Scotia. Memoirs of the Association of Australasian Palaeontologists, 29, pp.115-160.

von Bitter, P.H., And Plint, H.A. 1987. Conodonts of the Windsor Group (Lower Carboniferous), Magdalen Islands, Quebec, Canada. Journal of Paleontology, 61, pp. 346-362.

von Bitter, P.H., Giles, P.S., And Utting, J. 2006. Biostratigraphic correlation of major cycles in the Windsor and Codroy groups of Nova Scotia and Newfoundland, Atlantic Canada, with the Mississippian substages of Britain and Ireland. In Proceedings of the $\mathrm{XV}^{\text {th }}$ International Congress on Carboniferous and Permian Stratigraphy. Edited by Th. E. Wong. Royal Netherlands Academy of Arts and Sciences (Amsterdam), pp. 513-534.

Walkden, G.M. 1979. Cyclicity in Late Dinantian marine carbonates of Britain. Neuvième Congrès International de Stratigraphie et de Géologie du Carbonifère - Urbana. Compte Rendu, 3, pp. 561-569.

Editorial responsibility: Sandra M. Barr 